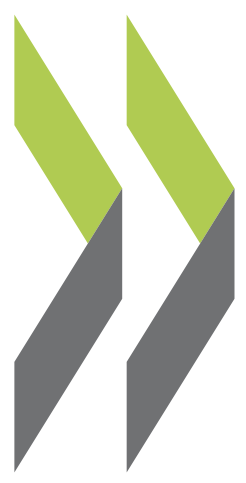

OECD Economics Department Working Papers No. 1133

Overcoming Vulnerabilities Falilou Fall, of Pension Systems Debra Bloch 
Organisation de Coopération et de Développement Économiques

Organisation for Economic Co-operation and Development

03-Jul-2014

ECONOMICS DEPARTMENT

English - Or. English

\section{OVERCOMING VULNERABILITIES OF PENSION SYSTEMS}

ECONOMICS DEPARTMENT WORKING PAPERS No. 1133

\section{Falilou Fall and Debbie Bloch}

OECD Working Papers should not be reported as representing the official views of the OECD or of its member countries. The opinions expressed and arguments employed are those of the author(s).

Authorised for publication by Jean-Luc Schneider, Deputy Director, Policy Studies Branch, Economics Department.

All Economics Department Working Papers are available through OECD's Internet website at http://www.oecd.org/eco/workingpapers

JT03360129

Complete document available on OLIS in its original format

This document and any map included herein are without prejudice to the status of or sovereignty over any territory, to the delimitation of international frontiers and boundaries and to the name of any territory, city or area. 
OECD Working Papers should not be reported as representing the official views of the OECD or of its member countries. The opinions expressed and arguments employed are those of the author(s).

Working Papers describe preliminary results or research in progress by the author(s) and are published to stimulate discussion on a broad range of issues on which the OECD works.

Comments on Working Papers are welcomed, and may be sent to the Economics Department, OECD, 2 rue André-Pascal, 75775 Paris Cedex 16, France, or by e-mail to eco.contact@oecd.org.

This document and any map included herein are without prejudice to the status of or sovereignty over any territory, to the delimitation of international frontiers and boundaries and to the name of any territory, city or area.

The statistical data for Israel are supplied by and under the responsibility of the relevant Israeli authorities. The use of such data by the OECD is without prejudice to the status of the Golan Heights, East Jerusalem and Israeli settlements in the West Bank under the terms of international law.

\section{() OECD (2014)}

You can copy, download or print OECD content for your own use, and you can include excerpts from OECD publications, databases and multimedia products in your own documents, presentations, blogs, websites and teaching materials, provided that suitable acknowledgment of OECD as source and copyright owner is given. All requests for commercial use and translation rights should be submitted to rights@oecd.org 
ECO/WKP(2014)29

\section{ABSTRACT/RÉSUMÉ}

\section{Overcoming vulnerabilities of pension systems}

Demographic developments are unfavourable for the financing of pension schemes in most OECD countries, implying continued growth in pension expenditure in virtually all OECD countries. This paper examines the vulnerability of pension systems, with an emphasis on financial sustainability and adequacy. Policy trade-offs and complementarities are reviewed and flanking policies which could underpin successful pension reforms are examined. Automatic adjustment mechanisms are highlighted, as are the roles of prudential regulation and buffer or reserve funds in the case of shocks. Pension system vulnerability indicators are presented for all OECD countries, and the challenges and vulnerabilities of pensions systems in the BRIICS countries are reviewed.

JEL classification: H55; H75; J32

Keywords: Pension, defined-benefit schemes, defined-contribution schemes, pension sustainability, ageing

$$
* * * *
$$

\section{Surmonter les vulnérabilités des systèmes de retraite}

Les évolutions démographiques sont défavorables au financement des systèmes de retraite dans la plupart des pays de 1'OCDE et se traduisent par une hausse des dépenses. Ce document examine la vulnérabilité des systèmes de retraites en se focalisant sur la durabilité financière et le niveau adéquat des pensions. Les complémentarités et les choix de politiques sont analysés ainsi que les politiques d'accompagnement qui pourraient sous-tendre une réussite des réformes des retraites. Les mécanismes d'ajustement automatique sont mis en évidence ainsi que le rôle de la régulation prudentielle, des fonds tampons ou de réserves en cas de chocs. Des indicateurs de vulnérabilité des systèmes de retraite sont présentés pour tous les pays membres de l'OCDE, de même, les défis et vulnérabilités des systèmes de retraite des pays BRIICS sont passés en revue.

Classification JEL : H55 ; H75 ; J32

Mots clés : Retraite, prestations définies, contributions définies, durabilité, vieillissement 


\section{TABLE OF CONTENTS}

OVERCOMING VULNERABILITIES OF PENSION SYSTEMS ..................................................... 6

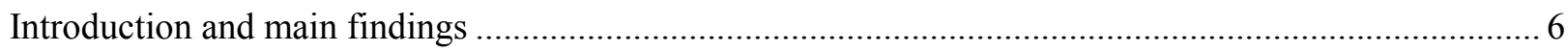

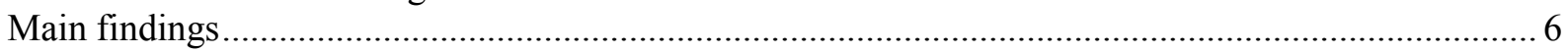

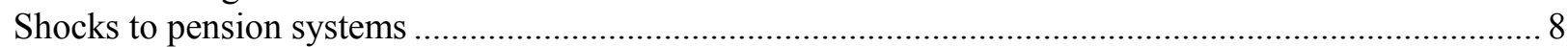

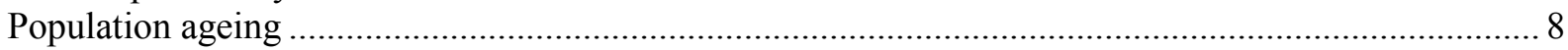

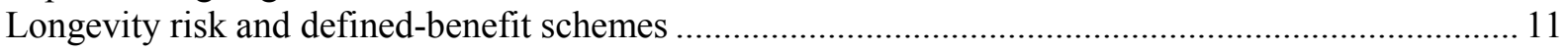

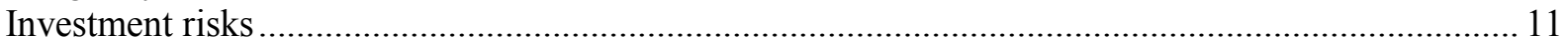

Policies favouring the sustainability of pension schemes ................................................................ 12

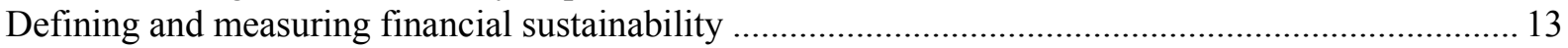

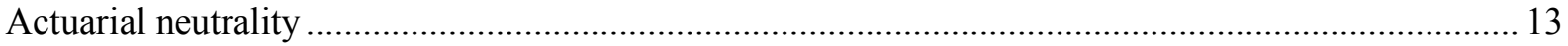

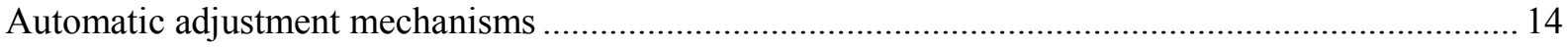

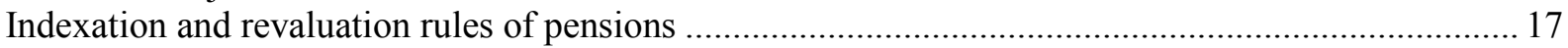

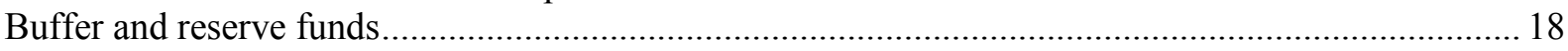

Prudential regulation and investment strategies to preserve the sustainability

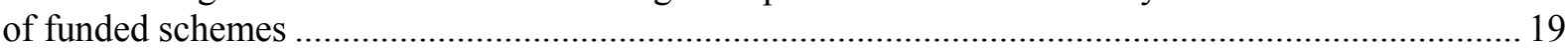

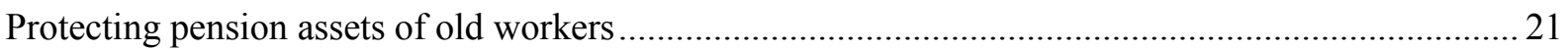

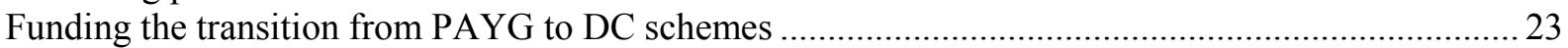

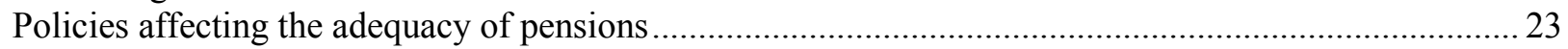

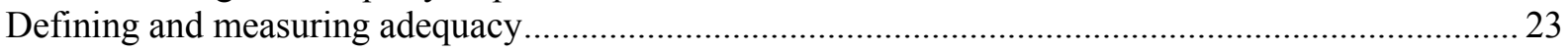

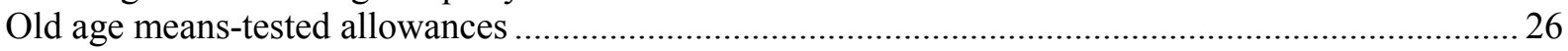

Public-private mix and extending private pension coverage .............................................................28

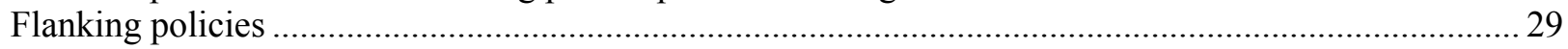

Preventing early retirement and exit from the labour market ................................................................29

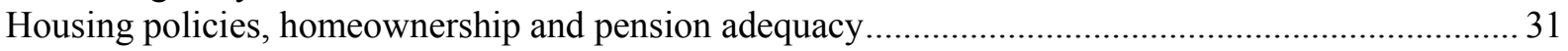

Policies play an important role in shaping the vulnerability of pension systems ..................................... 31

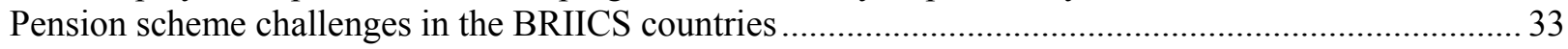

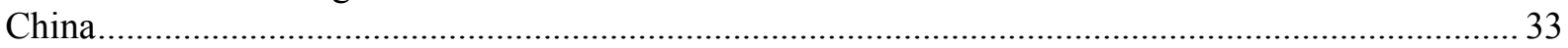

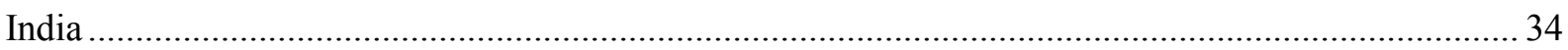

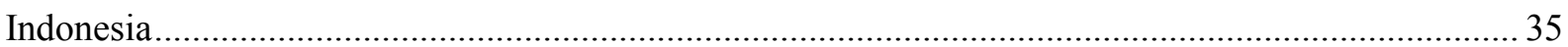

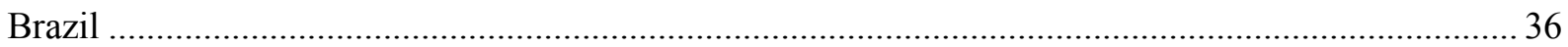

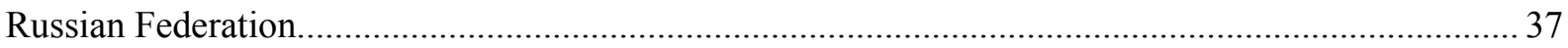

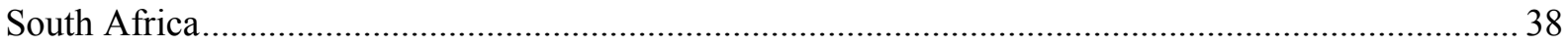

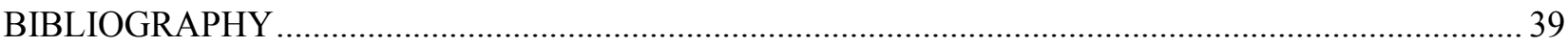

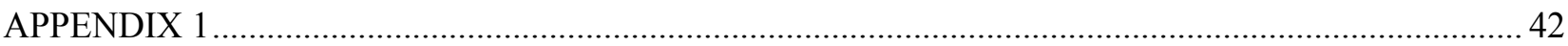

\section{Tables}

1. Automatic adjustment mechanisms to ensure the sustainability of pension schemes ...................... 15

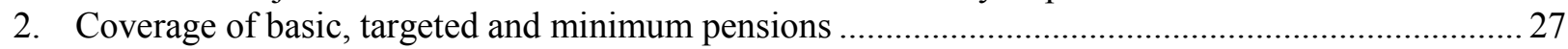




\section{Figures}

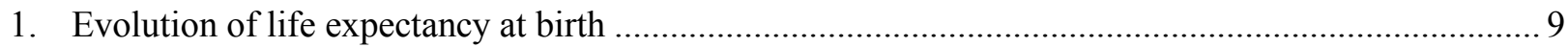

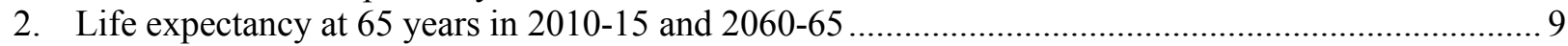

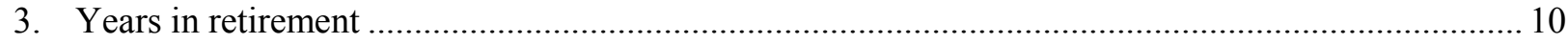

4. Populations are ageing and the old-age support ratio will halve in the OECD .............................. 11

5. Calculated average real net investment return of pension funds ................................................... 12

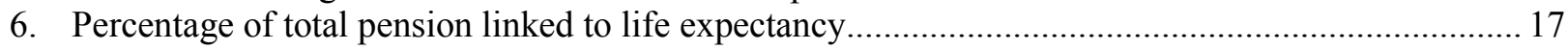

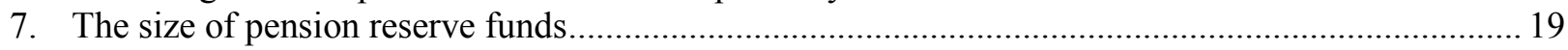

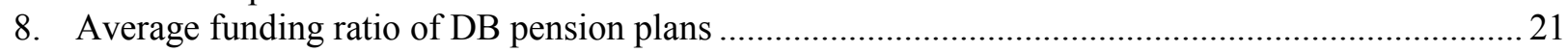

9. Net pension replacement rates from public and mandatory private schemes

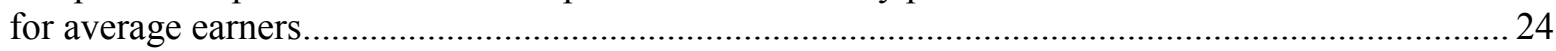

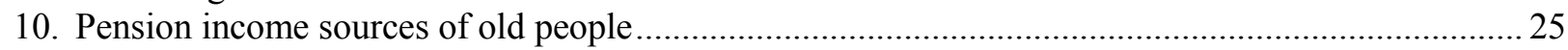

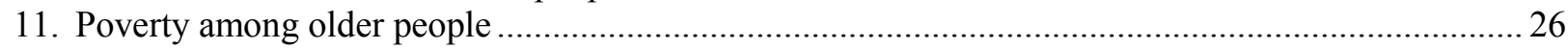

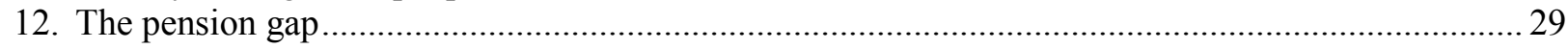

13. Average effective age of labour market exit and normal pensionable age ..................................... 30

14. Comparing vulnerability indicators for the Netherlands and the Slovak Republic ............................ 32

15. Support ratio and public pension expenditure in the BRIICS countries ........................................... 33

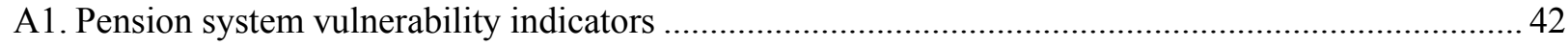

\section{Box}

Box 1. Political economy of reforms: Independent bodies and consensus building 


\title{
OVERCOMING VULNERABILITIES OF PENSION SYSTEMS
}

\author{
By
}

Falilou Fall and Debbie Bloch ${ }^{1}$

\section{Introduction and main findings}

1. Pension schemes have been reformed in most OECD countries over the last twenty years to cope with the demographic trend towards ageing populations. However, more efforts are needed to ensure the long run financial sustainability of pension schemes while preserving pension adequacy. Moreover, pension systems face challenges related to structural factors, such as productivity or migration trends, that can have important impacts on their financing. Short-run developments, as illustrated by the recent crisis, can also have significant impacts on pension schemes. For instance, investment returns of private funded schemes were hard hit during the crisis.

2. This paper is part of an OECD project on the Vulnerability of Social Institutions. The analysis has benefited from data gathered by the OECD (Pensions at a Glance 2013 and Pension Markets in Focus). Its aim is to better understand the vulnerability of pension systems to different shocks and long-term trends, and to draw policy lessons for pension reforms from various country experiences.

3. The main findings are:

- Demographic shocks are a main source of vulnerability of pension systems. Demographic developments are unfavourable to the financing of pension systems in most OECD countries, because of rising life expectancy and declining fertility rates. The resulting decline in the old age support ratio is particularly challenging for pay-as-you-go (PAYG) pension schemes as pension spending is financed by contributions of current workers. This is compounded by lasting effects of the recent crisis and slowing productivity growth.

- Pension spending will continue to increase in virtually all OECD countries. Public pension spending is projected to increase up to 2050 in all OECD countries except Estonia, Denmark and Poland. According to EU projections, given current legislation, pension systems will be in deficit in fourteen EU-OECD countries in 2060. Thus, there is a need to ensure the financial sustainability of pension systems. In most BRIICS countries, even though pension system coverage is far from universal, pension spending is already weighing on public finances.

1. The authors are members of the Economics Department of the OECD. They thank Anna d'Addio, Pablo Antolin, Hervé Boulhol, Jørgen Elmeskov, Peter Hoeller, Jon Pareliussen, Mauro Pisu, Monika Queisser and Jean-Luc Schneider for comments on earlier drafts and Celia Rutkoski for assistance in preparing the document. 
- The sustainability of pension systems can be ensured by a combination of different policy measures. Many countries are phasing in increases in the retirement age to restore the financial health of pension schemes. Adjusting key parameters automatically to cope with changes in structural variables can increase the financial robustness of pension systems. Many countries have introduced adjustment mechanisms to take into account changes in life expectancy. The adjustment can link the pension level, retirement age or contribution period to life expectancy. Increasing the contribution rate would improve financial sustainability, but could have a negative impact on labour markets.

- Various policy levers exist that can bolster the sustainability of funded pension schemes. In particular, a sound prudential regulatory framework for private and defined-contribution schemes is needed to protect individuals' pensions. Prudential regulation should aim to balance the trade-off between the prevention of excessive risk-taking and the goal of high returns on investments. Also, buffer and reserve funds, which exist in many countries, can play an important role as smoothing tools in the case of shocks. They can be used to avoid annual parametric changes of pension schemes, thereby limiting uncertainties.

- Pension reforms already enacted to ensure financial sustainability raise pension adequacy issues as replacement rates from mandatory pension schemes are expected to decrease in the future in some countries. The adequacy of pensions is already an issue in some OECD countries with regard to old age poverty. On average, $13 \%$ of the over 65 year olds in OECD countries live in poverty.

- Different policies can improve the adequacy of pensions. For instance, indexation and revaluation rules of pensions play an important role in determining the pension level. They should be designed in a way that balances their sustainability and adequacy impact. Too high indexation and revaluation rates increase pension spending while too low indexation of pensions will create adequacy issues in the long run, particularly among the older pensioners. However, specific rules can guarantee that pension levels for pensioners with full contribution periods remain above the poverty line. Old age safety nets are in general means-tested and designed to complement pensions, but in order to respect the "making work pay" principle, means-tested benefits should provide less revenue than work-based pension income. Finally, increasing coverage of voluntary private pensions should be a prime objective in countries where they represent an important complement to (relatively low) public pensions.

- The success of pension reforms depends also on flanking policies. In most countries, the retirement age has been increased and early retirement schemes phased out to improve the financial sustainability of pension schemes. The success of these policies depends on well-functioning labour markets, in particular for older workers. In 19 OECD countries the effective age of labour market exit is lower than the official retirement age for both men and women. Reforms are needed to raise the employment rate of older workers, particularly in countries that lag far behind in this respect. Reforms should include a better screening of access to long-term disability schemes, changes to the implicit tax on continued work by increasing the bonus for deferred retirement up to the actuarially neutral level, favouring the development of part-time work for older workers and enabling the combination of work with pension receipt.

- For the BRIICS countries the main challenge is to develop comprehensive and sustainable pension systems. Though the current dependency ratio is still favourable in these countries, it will converge rapidly to the OECD average, with the exception of South Africa and India. Financial sustainability issues are already lurking due to the generosity of the pension system (Brazil), insufficient funding and fragmentation of pension schemes (China), early retirement (Indonesia), carry-over of unfunded past liabilities (India and Russia) and important safety net benefits (South Africa). The importance of 
the informal sector with many low income earners undermines the adequacy of pensions and is a significant barrier to overcome in establishing universal coverage of pension systems.

4. Section 2 of this paper presents the patterns of population ageing in the OECD and BRIICS countries. Section 3 presents the policy levers to enhance the financial sustainability of pension systems in the face of shocks and section 4 discusses the adequacy of pension schemes, drawing out policy trade-offs and complementarities. Section 5 reviews flanking policies that can underpin the success of pension reforms. Section 6 gathers together various vulnerability indicators and compares them with the OECD average. The final section reviews the challenges and vulnerabilities facing the BRIICS countries.

\section{Shocks to pension systems}

5. Pension schemes are also exposed to trend changes of productivity and migration. As developed in Fall (2014), productivity and migration trends reversal have long lasting transitory effects. ${ }^{2}$ Over the long run, population ageing puts upward pressure on spending and this is further discussed in this section along with longevity and investments risks.

\section{Population ageing}

6. The ageing of societies has two components: the decrease of fertility rates and the increase of life expectancy. In all OECD countries, life expectancy has increased since the 1970s (Figure 1). The BRIICS countries have also seen important gains in life expectancy. Only South Africa has experienced a decline in life expectancy, due to the AIDS epidemic.

7. One striking feature of this ageing trend is the gain in life expectancy at 65 years. In most OECD countries, life expectancy at 65 reaches 20 years for women and 15 years for men (Figure 2). Life expectancy at old age for the BRIICS countries is still below the OECD average, with the gap being wider for women than for men. Russia and South Africa are exceptions with an exceptionally low life expectancy at 65 for men.

2. Fall (2014) is a companion working paper which presents detailed simulations of stylised PAYG pension schemes. 
Figure 1. Evolution of life expectancy at birth

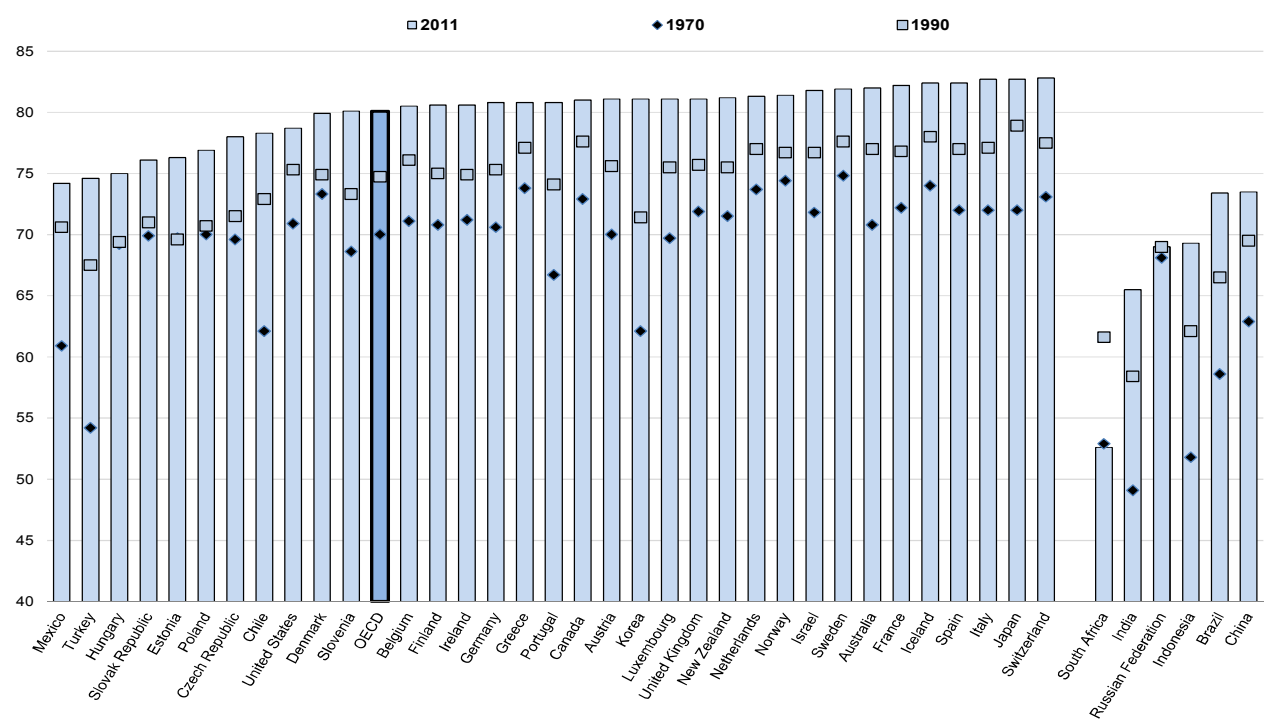

Note: For Canada, Israel, Italy and Luxembourg, 1970 data refer to 1971. For Canada, the 2011 data refer to 2009.

Source: OECD Health Data, accessed 4 November 2013 and OECD Health at a Glance 2013.

Figure 2. Life expectancy at 65 years in 2010-15 and 2060-65
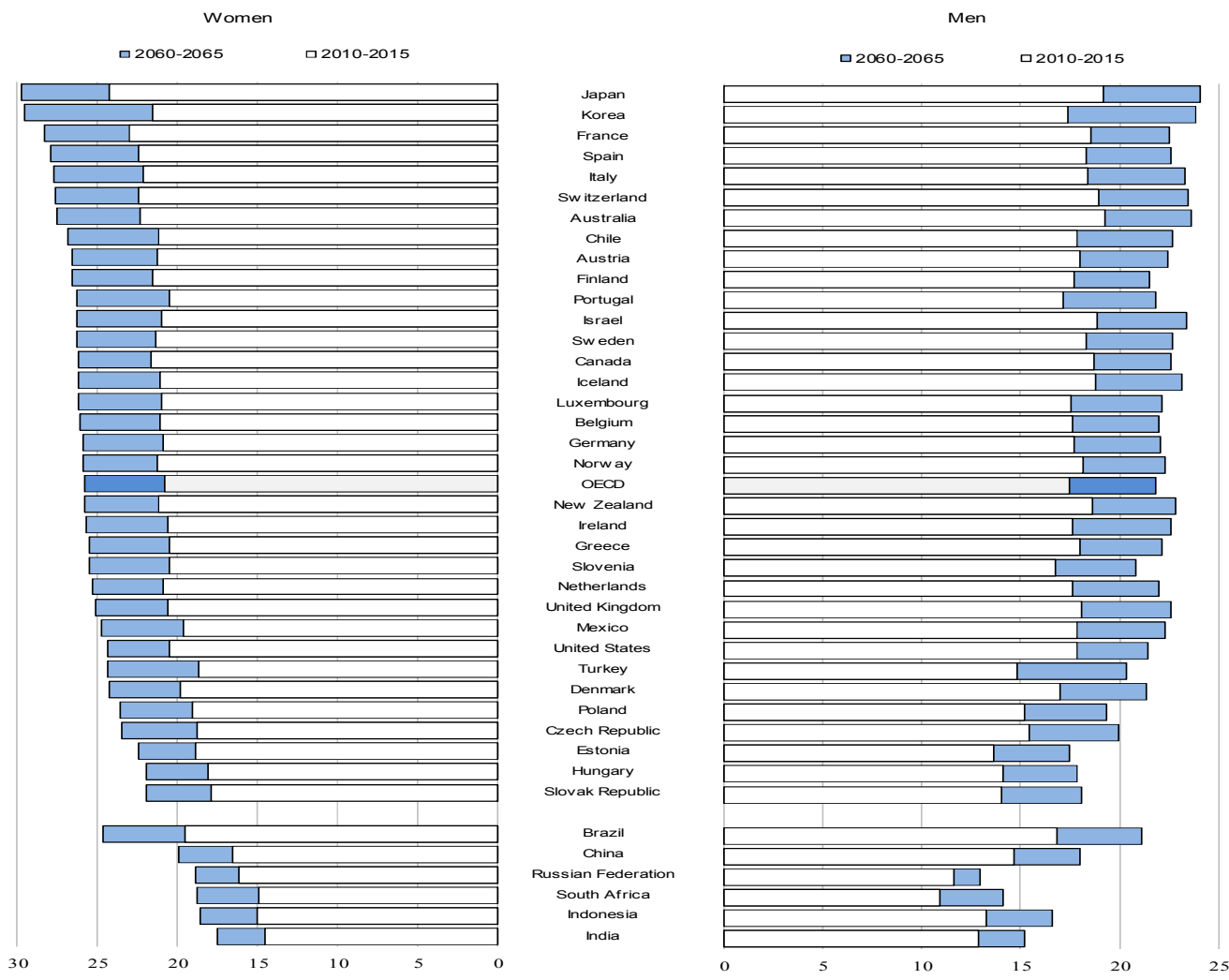

Source: OECD (2013), Pensions at a Glance 2013: Retirement-Income Systems in OECD and G20 Countries. 
8. The rise in life expectancy has induced an increase in the duration of retirement even if the retirement age has been raised progressively in many countries. The average OECD duration of retirement is 22.5 years for women and 18.1 for men. Figure 3 shows that the duration of retirement is highest at 27.4 years for women in France (as of 2012 legislation) and 23.4 years in Luxembourg for men.

Figure 3. Years in retirement

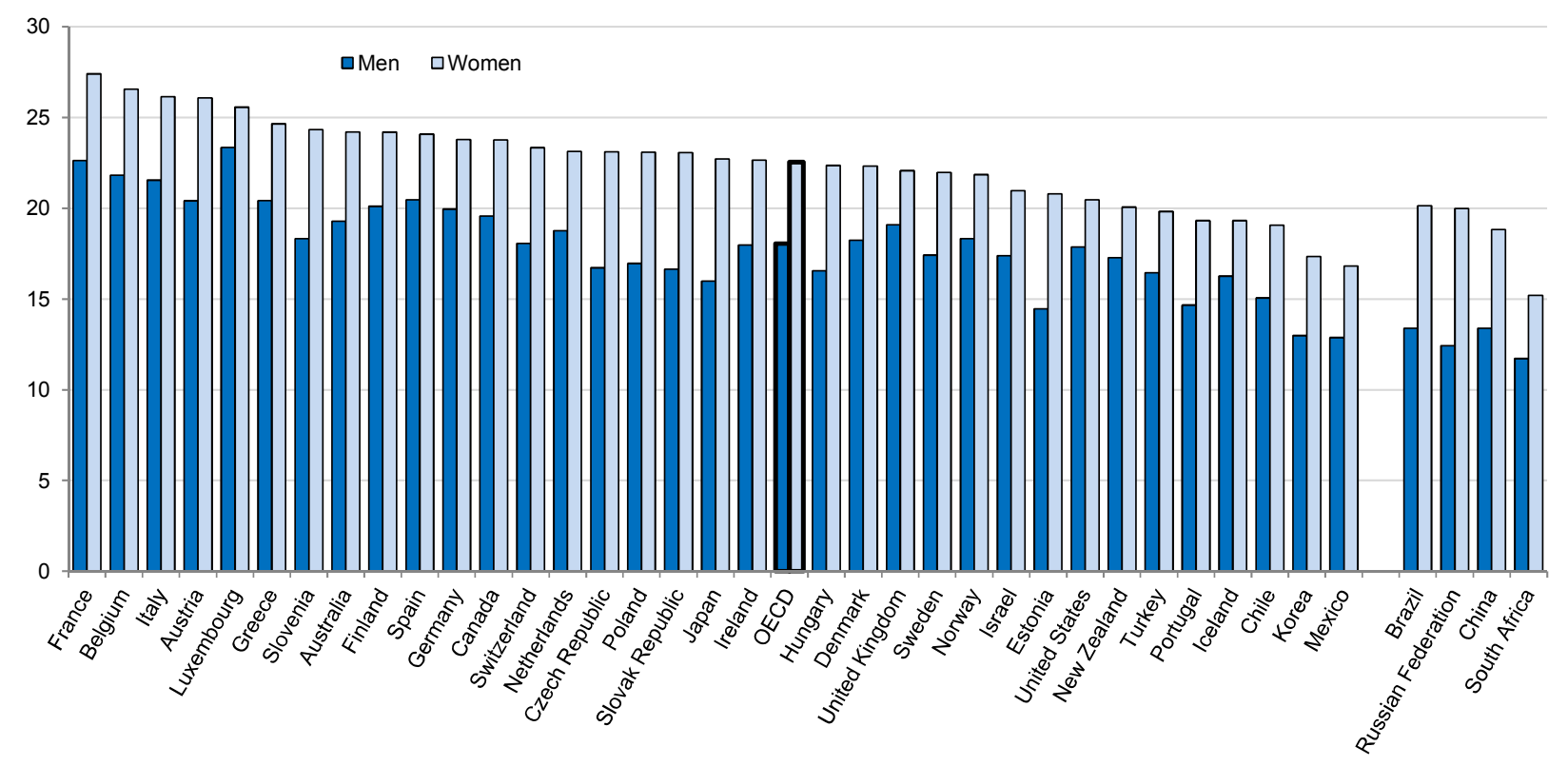

Note: The expected duration of retirement is calculated as the difference between life expectancy at the effective age of labour market exit and the pensionable age in 2012. Data refer to 2011 for Brazil and 2010 for China, 2009 for Chile, and 2008 for women in Turkey instead of 2012; the data for women in Turkey from 2009 onwards are not shown because participation rate changes have led to net entries into the labour market rather than net exits for some of the older age cohorts and hence to unreliable estimates of the effective age of retirement.

Source: OECD (2014), Society at a Glance 2014: OECD Social Indicators.

9. Life expectancy gains are combined with a decrease in fertility rates in almost all OECD countries. These two phenomena are jointly lowering the old-age support ratio (the working age population (20-64) over the retirement age (65+) population). It is projected that between 2010 and 2050, the average OECD old-age support ratio will be halved from 4.4 to 2.1 (Figure 4). Japan is expected to have the lowest support ratio (1.3) in 2050, while Mexico is projected to show the most rapid decline (going from 9.1 to 2.8). Figure 4 illustrates the rapid convergence of the old age support ratios for OECD countries as well as the rapid ageing in the BRIICS countries. 
Figure 4. Populations are ageing and the old-age support ratio will halve in the OECD

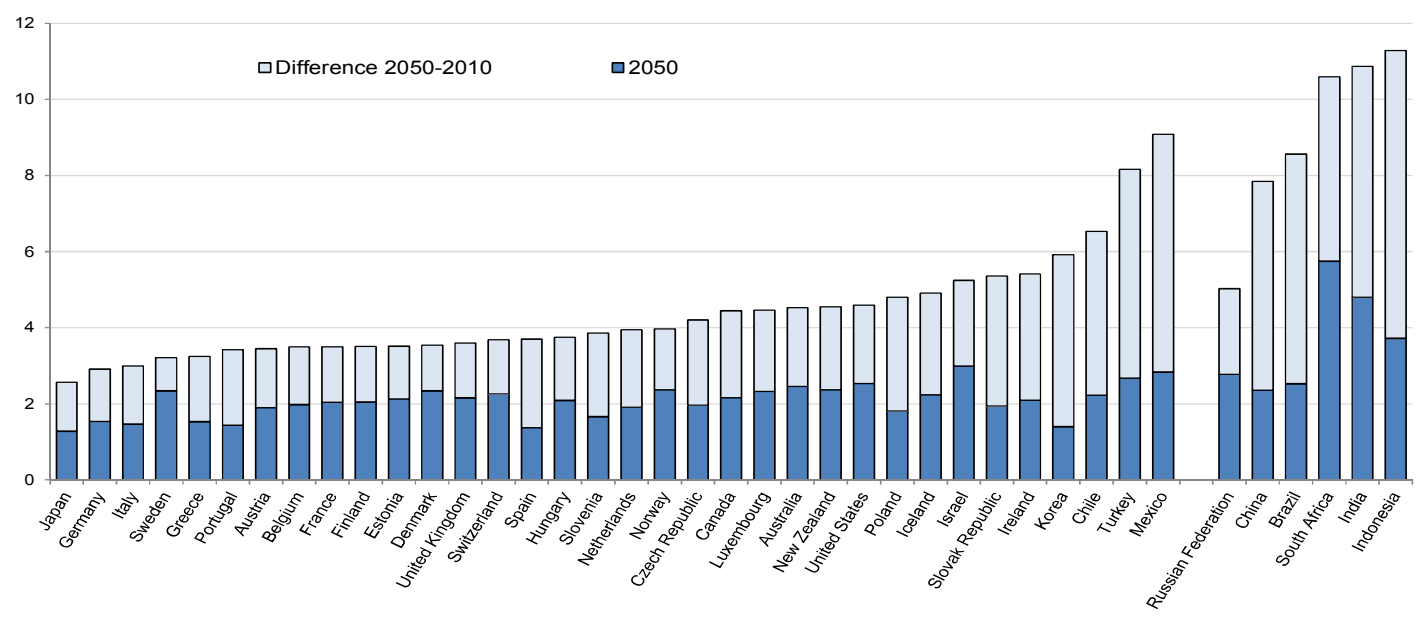

Source: OECD (2013), Pensions at a Glance 2013: Retirement-Income Systems in OECD and G20 Countries.

\section{Longevity risk and defined-benefit schemes}

10. Defined-benefit plans are exposed to uncertainties surrounding future life expectancy developments. Public pension systems and private pension funds providing defined pension benefits need to assess the number of future pensioners based on long-term projections. Longevity risk is the risk that actual life spans of individuals or of whole populations will exceed expectations.

11. IMF (2012) and Antolín (2007) show that projections consistently underestimated improvements in mortality and life expectancy in the past. The underestimation pertains partly to the projection method and the lack of data for the very old (those aged 85 and above). Forecasting models of longevity can be divided into (i) methods that use the underlying drivers of mortality (economic, environmental and epidemiological factors) to estimate future mortality rates and (ii) extrapolative methods that prolong historical trends. Extrapolative methods can be deterministic or stochastic.

12. Studies show that, on average, life expectancy has been underestimated by three years. According to IMF (2012) estimates, the additional cost of providing individuals of age 65 and over with a 60 to $80 \%$ replacement rate for those additional three years adds between 1.5 and 2.0 percentage points of GDP to the annual cost of ageing in advanced economies in 2050, and 1.0 to 1.3 percentage points of GDP in emerging economies.

13. The uncertainties about future life expectancy are not fully taken into account by pension funds. In some countries, pension funds incorporate an allowance for uncertainty about future improvements in mortality, while others use tables that relate to past mortality developments, without accounting for future gains in life expectancy (Belgium, Denmark, Norway, Sweden, and Switzerland) (Antolín, 2007).

\section{Investment risks}

14. Private pension plans are exposed to investment risks as they seek to maximise investment returns. The recent crisis illustrated the high uncertainty and risks surrounding investment in stocks (Figure 5). OECD (2009) estimates that pension funds lost 23\% of their value in 2008, worth about USD 5.4 trillion. Figure 5 shows the average return, but in some countries such as the United States with a large proportion of their portfolios invested in equities, the losses were much greater at the onset of the crisis. 
15. D'Addio et al. (2009) using historical data on returns on equities and bonds in major OECD economies over the past quarter century show a median real return of $7.3 \%$ a year on a portfolio equally weighted between equities and bonds (averaging across the countries studied). It might be expected that, over a very long period, the degree of uncertainty in investment returns is small. A few bad years in the market are likely to be offset by boom years. However, they found the degree of uncertainty to be large, even with the relatively long investment horizons of pensions.

16. In $10 \%$ of cases, an annual return of less than $5.5 \%$ would be expected, while in $10 \%$ of cases, this should exceed $9.0 \%$. Also, returns achieved by individuals on their pension funds are less than the market return due to administrative charges that can be large (OECD, 2013a), agency and governance effects.

Figure 5. Calculated average real net investment return of pension funds

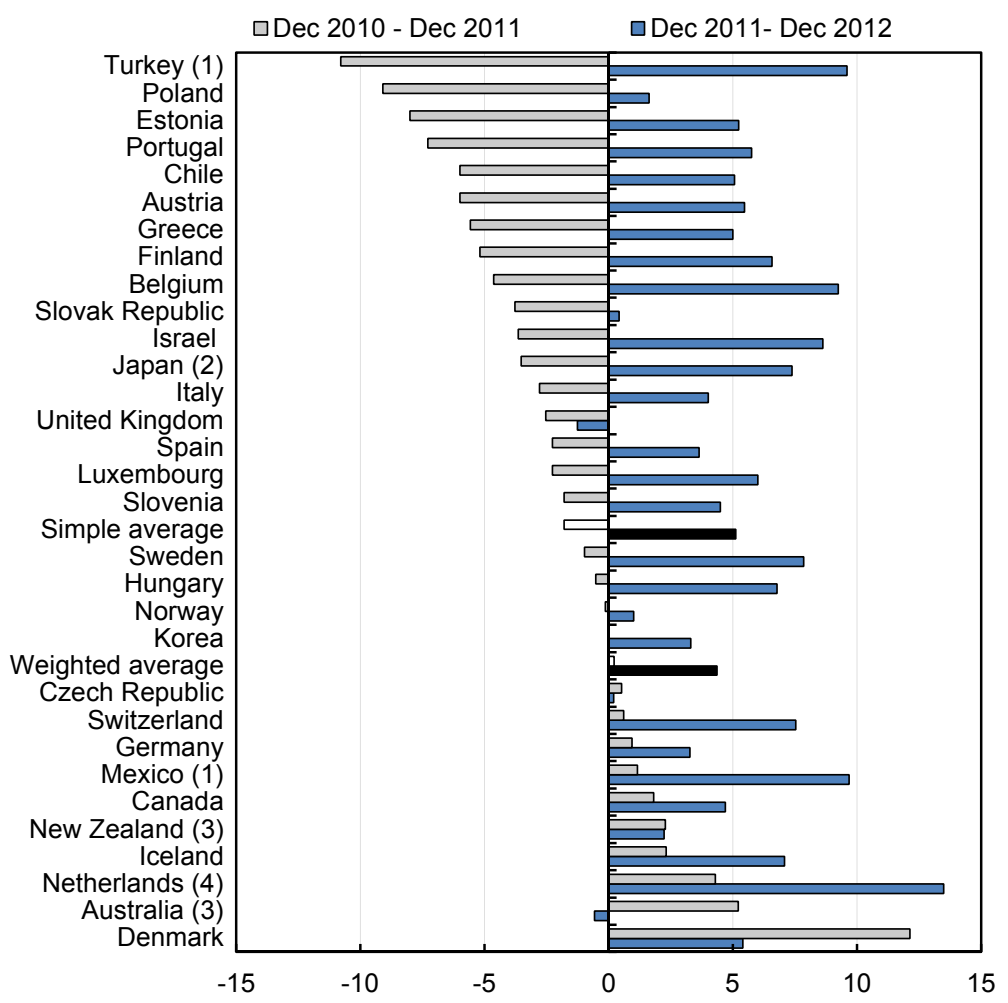

Note: Data have been calculated using a common formula for the average nominal net investment return (ratio between the net investment income at the end of the year and the average level of assets during the year). Average real net investment returns have been calculated using the nominal interest rate and the variation of the end-of-period consumer price index between 2010 and 2011 , and 2011 and 2012 for all countries, except for Austria, Israel, Korea, and Sweden, for which values have been provided by the countries. The 2010-Q2, 2011-Q2 and 2012-Q2 consumer price index per year have been used for Australia and New Zealand. Averages are calculated over countries for which data for both 2011 and 2012 are available.

1. Data refer to personal pension plans only.

2. Source: Bank of Japan.

3. The average rates of return are calculated over the period June 2010-June 2011, and June $2011-J u n e ~ 2012$.

4. Data for 2012 are preliminary.

Source: OECD Global Pension Statistics. OECD Pension Markets in Focus 2013.

\section{Policies favouring the sustainability of pension schemes}

17. Policy reforms aimed at addressing the effects of shocks on pension systems need to balance financial sustainability and adequacy concerns. Both sustainability and adequacy are critical, but policy 
reforms often face a trade-off between these two goals. Flanking policies, for instance, those that raise employment, ease the trade-off as more revenues are provided.

\section{Defining and measuring financial sustainability}

18. Financial sustainability reflects the ability of pension systems to meet their liabilities in the medium to long term. This can be measured by the long-term actuarial balance of the system. Sustainability implies that the discounted present value of the stream of contributions and other revenues over a long horizon is sufficient to cover projected benefits.

\section{Actuarial neutrality}

19. The actuarial neutrality of pension schemes' rules affects defined-benefit (DB) and definedcontribution (DC) schemes differently. The actuarial balance of pension schemes depends primarily on the actuarial balance at the individual level, which is reached when life time pensions received are equal to overall career contributions. There is thus no redistribution: what people receive in retirement is the same as what they paid in when working, together with the investment returns on the accumulated assets before retirement.

20. However, the balance between contributions and pensions also depends on the parameters (contribution rate, rate of return, official retirement age) of the pension schemes and on individual choices (retirement age decision) and characteristics (wage profile and life expectancy). The parameters of the scheme should be chosen carefully to ensure that for the average individual actuarial neutrality is guaranteed, in order to encourage individual choices that satisfy overall actuarial neutrality.

21. Different pension schemes are exposed differently to the risk of not satisfying the actuarial neutrality principle. Defined-contribution schemes and notional defined-contribution schemes (NDC) are less exposed to non-actuarial neutral pricing (setting of the parameters of the scheme), because there are less options for individual choice or characteristics that affect the balance. In DC schemes, as all contributions are taken into account in defining the pension level, it is the market rate of return which affects the pension level. Instead, in point and NDC schemes the rate of return has to be selected so as to ensure the actuarial balance and has to be eventually adjusted to take into account the evolution of life expectancy.

22. Defined-benefit schemes are more prone to violate the actuarial neutrality principle, because pension benefits are not strictly linked to contributions. In many countries, the whole career is not taken into account when determining the reference wage. In France, for instance, it is the best 25 years that are chosen for private sector workers, while in other countries it is sometimes only the final years. In general, this implies a reference wage over which the pension benefit is calculated which is higher than the average wage. This reduces the contributory dimension of the scheme and undermines actuarial neutrality. Also not adjusting the retirement age to rising life expectancy can alter actuarial neutrality.

23. Moreover, actuarial neutrality at the margin can be important, if pension reforms seek to provide incentives for individuals to delay their retirement. One way to define actuarial neutrality at the margin is that marginal contributions (one additional year of work, for instance) equal marginal benefits ${ }^{3}$ and bonuses for delaying retirement or penalties for early retirement should be set accordingly. The difficulty is to set up a unique scale for individuals with different characteristics (life expectancy differences by sex or income level).

\footnotetext{
3. See Queisser and Whitehouse (2006) for different definitions of actuarial neutrality at the margin.
} 


\section{Automatic adjustment mechanisms}

24. Automatic adjustment of pension system parameters allows pension financing to be closely aligned with demographic and economic trends. Like other pre-commitment mechanisms in economic policymaking - in monetary and fiscal policy, for example - it is designed to enhance credibility and provide assurance that public pension schemes will not place an unexpected burden on public finances in the future.

25. The financial sustainability of a pension scheme is governed by the relationship between its parameters (contribution rates and periods, retirement age, valorisation and indexation) and demographic dependency variables. Current or expected prolonged deficits can occur due to a mismatch between spending (overly generous pensions, ageing populations) and funding (too low contribution rate, slump in payroll or income base and employment or lower productivity). Given the difficult process of pension reform, many countries have introduced automatic adjustment mechanisms to cope with trend changes or shocks that threaten the actuarial equilibrium (Table 1). ${ }^{4}$ Automatic adjustment mechanisms can be an alternative to frequent and difficult pension reforms (see Box 1).

4. See Chapter 2 in OECD (2012). 
ECO/WKP(2014)29

Table 1. Automatic adjustment mechanisms to ensure the sustainability of pension schemes

\begin{tabular}{|c|c|c|c|c|}
\hline & $\begin{array}{c}\text { Link of } \\
\text { pension } \\
\text { benefit to life } \\
\text { expectancy }\end{array}$ & $\begin{array}{l}\text { Pension } \\
\text { valorisation and } \\
\text { indexation }\end{array}$ & $\begin{array}{c}\text { Retirement } \\
\text { age }\end{array}$ & $\begin{array}{c}\text { Contribution } \\
\text { rate }\end{array}$ \\
\hline Australia & $x$ & & & \\
\hline Canada & $X$ & $x$ & & $X$ \\
\hline Chile & $x$ & & & \\
\hline Czech Republic & & & $X$ & \\
\hline Denmark & & & $x$ & \\
\hline Estonia & $\mathrm{X}$ & & & \\
\hline Finland & $x$ & & & \\
\hline France & & & $\mathrm{X}^{1}$ & \\
\hline Germany & $x$ & $x$ & & $x$ \\
\hline Greece & & & $\mathrm{X}$ & \\
\hline Ireland & $x$ & & & \\
\hline Israel & $x$ & & & \\
\hline Italy & $x$ & & $x$ & \\
\hline Japan & $x$ & $x$ & & $x^{2}$ \\
\hline Mexico & $x$ & & & \\
\hline Netherlands & & & $x^{3}$ & \\
\hline Norway & $x$ & & & \\
\hline Poland & $x$ & & & \\
\hline Portugal & $x$ & $x$ & & \\
\hline Slovakia & $x$ & & & \\
\hline Sweden & $x$ & $x$ & & \\
\hline United Kingdom & $x$ & & & \\
\hline United States & $x$ & & & \\
\hline
\end{tabular}

Note: Pension valorisation refers to rates applied to past contributions or past wages in DB schemes that determine their value at the retirement date. Indexation refers to annual pension increases, including rates of return in NDC schemes. Link of pension benefit to life expectancy may be partial.

1. For France, it is the contribution period for the receipt of a full pension which is linked to life expectancy and the adjustment is not completely automatic as the government has to enact it.

2. For Japan, the measures are temporary up to 2017.

3. For the Netherland, the retirement age will be adjusted to life expectancy from 2023 after the pension age has gradually increased to 67 years.

Source: OECD (2012b), OECD Pensions Outlook 2012.

\section{Box 1. Political economy of reforms: Independent bodies and consensus building}

Different factors shape the success of pension reforms. Having an independent body in charge of the assessment of pension schemes, of the projections of pension expenditure and the evaluation of the impact of demographic changes is very helpful at least for the diagnosis and acceptance of the need for reform (EU-EPC-AWG projections; France, Sweden and Belgium among others have independent bodies in charge of the assessment of the pension system). ${ }^{1}$ Ad hoc Commissions also played an important role (Germany, Sweden and United Kingdom) in preparing reforms and building consensus. Building trust in such institutions can take time, as their effectiveness depends greatly on their reputation, but in countries where they exist, it appears that they have enhanced the prospects for reform (Tompson, 2009).

Economic and financial crises may make pension reforms inevitable (OECD, 2010a). In deep recessions, the fall in pension contributions, which are typically linked to the payroll, may threaten the payment of pension benefits 
(Greece during the crisis), unless compensatory transfers from the central government are provided. Crisis may thus make an increase in the retirement age or a reduction in pension benefits, at a time when sacrifices are necessary also elsewhere in the economy, more acceptable.

The success of reforms depends on country-specific factors and the national political landscape. However, OECD (2010a) shows that there are common factors that favour success. For instance, sequencing measures affecting different groups is a strategy that has been successfully applied in pension and other reforms. However, sequencing implies that it may take time to accomplish the overall agenda. The French pension reform started in 1993 with changes in pension rules, in 2003 contribution periods were increased, in 2008 special regimes were reformed, in 2010 the retirement age was increased and in 2013 contribution periods were further increased and contribution rates are planned to rise. In the Swedish case pension reform was an overhaul started by setting up a commission in 1991, but the first payment of pensions under the new scheme started only in 2003.

1. Hagemann (2011) and Curristine et al. (2013) review fiscal council functions and impacts.

\section{Adjustment of benefit levels}

26. Pension benefits in payment can be reduced through automatic indexation rules which take into account financial imbalances (Canada, Germany, Japan, Portugal and Sweden). In Finland, the life expectancy coefficient automatically adjusts the amount of pensions in payment as life expectancy changes. In Sweden, indexation of pension benefits and of accumulated notional capital, are adjusted automatically, when the balancing ratio (current liabilities of the pension system) is below one. However, the way the adjustment is realised can lead to unintended intergenerational redistribution. For Sweden, Barr and Diamond (2011) show that the balancing mechanism, activated for the first time in 2008 with application in 2010, was unfavourable to retirees compared to workers.

\section{Pension indexation}

27. Changing the indexation method (adjustment to reflect changes in living standards between the time that the pension entitlement was earned and when it is paid) from wage to price indexation will lower the relative pension level. ${ }^{5}$ In Japan, the switch from wage to inflation indexation was an integral part of the automatic balancing mechanism introduced in 2004. In Germany, the revaluation of retirement points (which determine the pension level) takes into account the evolution of the demographic dependency ratio.

\section{Adjusting for life expectancy developments}

28. Many countries have introduced adjustment mechanisms to take into account changes in life expectancy. The adjustment can link the pension level, the retirement age or the contribution period to life expectancy. In notional defined-contributions schemes (Sweden, Chile, Estonia, Mexico and Italy) and some defined-contributions plans, accumulated contributions and investment returns are converted into a pension or annuity in retirement, with the conversion factor depending on life expectancy. Denmark, Greece and Italy have introduced reforms to index the retirement age to life expectancy. In France, the automatic adjustment mechanism targets the contribution period, which is adjusted according to life expectancy gains in order to maintain a constant ratio between the duration of activity $(2 / 3)$ and the expected duration in retirement $(1 / 3){ }^{6}$

\footnotetext{
5. It has been used as a one-off discretionary policy in France, Germany and Sweden.

6. In France the adjustment of the contribution period is semi-automatic as it still depends on a vote by parliament.
} 
29. Most countries have chosen to link pension benefits rather than retirement age to life expectancy (Figure 6), as the retirement age has already been raised in many countries and it is expected that individuals will delay their retirement in the face of declining pensions. However, as demographic and economic dependency ratios are both affected by life expectancy gains, and as these are the major determinants of pension scheme balances in PAYG systems, linking retirement age to life expectancy would better restore the balance of these schemes.

Figure 6. Percentage of total pension linked to life expectancy
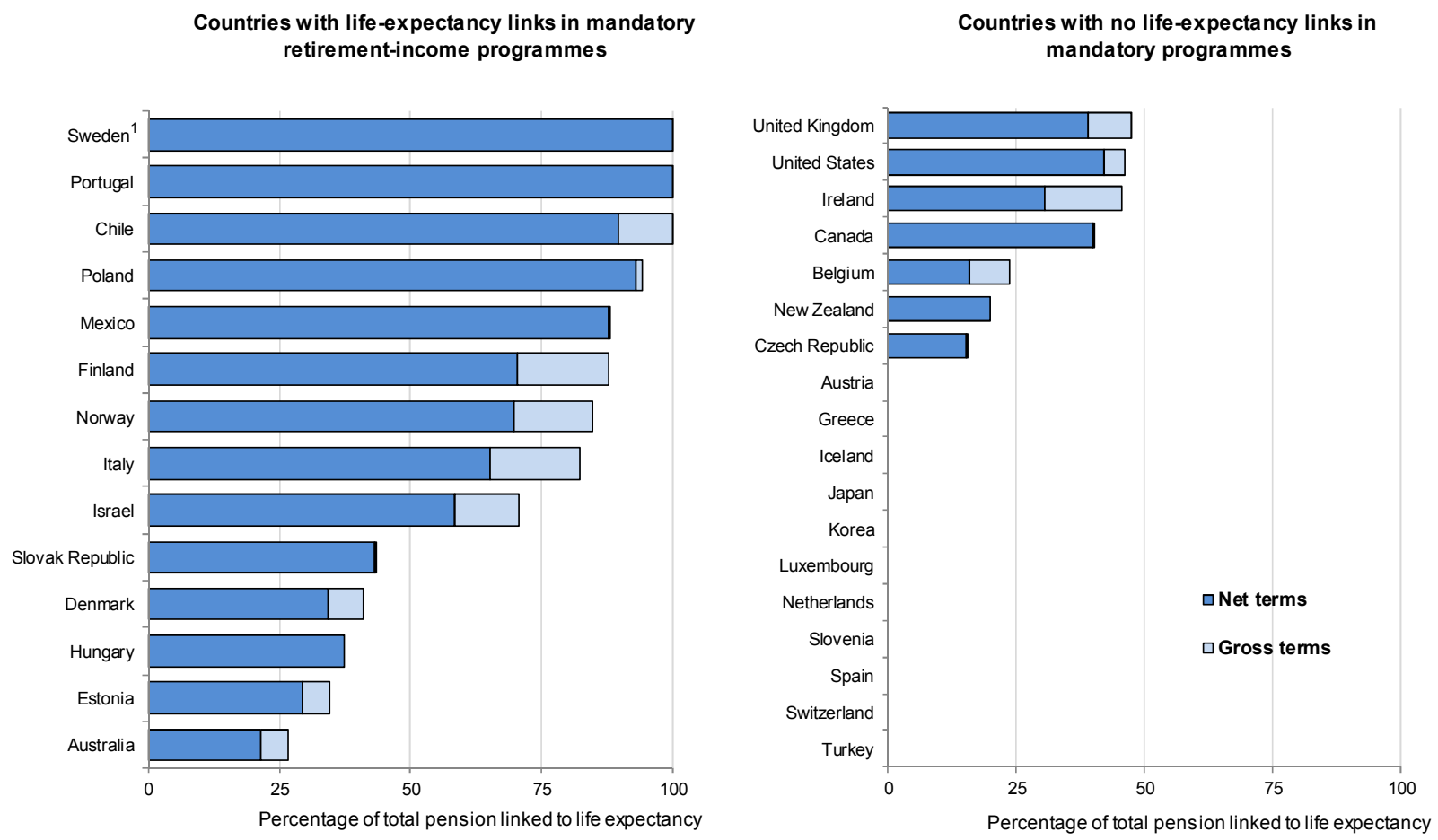

Note: Based on OECD Pension Model simulations for a person with average earnings entering the labour force in 2008. For countries in the right panel, the percentage of pension linked to life expectance refers to voluntary schemes.

1. Excludes the guarantee pension (defined-benefit scheme available from age 65 for persons with no or low income related pensions) which is not linked to life expectancy.

Source: OECD (2011), Pensions at a Glance 2011.

\section{Indexation and revaluation rules of pensions}

30. The indexation and revaluation rules of pensions play an important role in determining the level of pensions. First, they determine the level of the pension as they are used to up rate past contributions or income to determine the reference wage in DB schemes or the accumulated contributions in NDC schemes. Second, they determine the evolution of pensions during retirement. In many countries, pension indexation has shifted from the average nation-wide wage growth rate to inflation. Pensions are indexed to price inflation in 13 OECD countries, with a mix of wage and price weighting in six countries, with wage or part of wage inflation in five countries and a mix of price and GDP indexation in two countries.

31. However, governments tend to systematically override these rules (OECD, 2012), changing pension levels by larger or smaller amounts than implied by indexation. In the recent period, several countries chose to freeze pensions rather than reduce them (Finland, Slovenia and Austria and Italy for higher pensions) and they were sharply reduced in Greece. 
32. As prices tend to rise at a slower pace than earnings, indexing pensions to price developments increases financial sustainability. Indeed, it disconnects the growth rate of the funding base from the growth rate of spending. However, in the long run and for future generations, there is a risk of creating an important income gap between workers and older retirees. In some cases, it can increase the poverty rate of pensioners as increases in pension benefits are smaller than those of earnings.

\section{Buffer and reserve funds}

33. Short-run economic fluctuations and temporary demographic shocks can create imbalances and deficits in pension schemes. In order to avoid frequent parametric changes of pension schemes bringing about uncertainties, buffer or reserve funds can be built up as smoothing tools.

34. One can distinguish at least three different functions for buffer and reserve funds (Fall and Ferrari, 2008). First, they can be used to smooth the effects of fluctuations of the demographic dependency ratio along its long run trend. In the case of temporary demographic shocks (such as a transitory drop in the fertility rate, for example), it may be desirable to adapt the financial equilibrium constraint by introducing reserves. In that sense, a reserve fund is a means for smoothing the effects of temporary demographic shocks. Second, a reserve fund can be used to smooth temporary over-spending (compared to trend) resulting from any shock that affects the pension balances (temporary slump of payroll or arrival of large cohorts of pensioners at retirement). Such a fund would naturally fall to zero once the shock has been smoothed. Finally, a pension reserve fund can be designed as a permanent means of additional funding for the old-age insurance system. After the fund's build-up phase, its capital is preserved and its investment income contributes to the financing of pension spending. The returns from the fund act as a substitute to individual contributions or government transfers.

35. Many countries have pension reserve funds (Figure 7). Pension reserve funds were pioneered by the United States and Sweden in 1944 and 1960, respectively. Norway has a Government Pension Fund since 1990 and Japan a National Reserve Fund since 1959. 
Figure 7. The size of pension reserve funds

Per cent of GDP

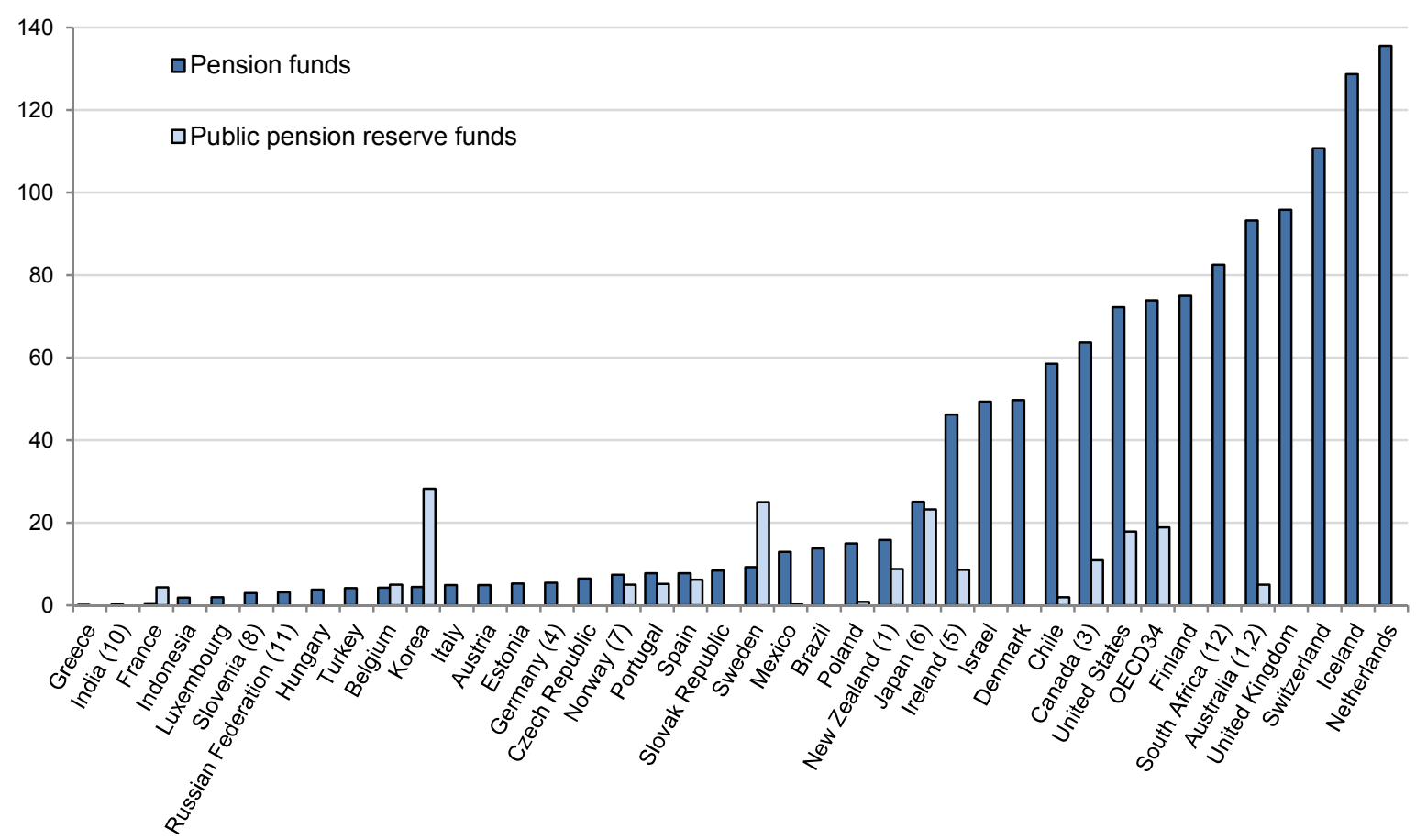

Note: "OECD34" represents the weighted average of funds' assets as a \% of GDP.

1. Data for pension funds refer to the end of June of each year.

2. State governments are believed to have some reserves set aside but these reserves are not included because they are too difficult

to determine.

3. Data refer to Canada Pension Plan Investment Board and Quebec Pension Plan.

4. Data refer to Pensionskassen and Pensionfonds.

5. The source for pension funds' data is the IAPF Pension Investment Survey. The value for the Irish Public Pension Reserve Fund includes both the discretionary portfolio and the directed portfolio (investment into Irish banks).

6. The source for pension funds' data is Bank of Japan.

7. The Government Pension Fund - Global, which was previously a sovereign wealth fund called the Government Petroleum Fund draws its funding from oil revenues and has a mandate that goes beyond financing pension expenditures; so it is not classified as a sovereign pension reserve fund. The figure in this table, therefore, only refers to the Government Pension Fund - Norway, formerly the National Insurance Scheme Fund (5.0\% of GDP). By contrast the total assets of the larger Government Pension Fund - Global, would amount to $121.7 \%$ of GDP.

8. Pension fund data only refer to mutual pension funds under the supervision of the Securities Market Agency of Slovenia.

9. In 2008, a pension reform diverted pension fund assets to the National Social Security Administration.

10. Data refer to PFRDA regulated funds only.

11. Data only refer to the mandatory part of the Russian system.

12. Data refer to 2010.

Source: OECD Global Pension Statistics, OECD (2013), Pensions at a Glance 2013: Retirement-Income Systems in OECD and G20 Countries. www.oecd.org/pensions/pensionsataglance.htm.

\section{Prudential regulation and investment strategies to preserve the sustainability of funded schemes}

36. The goal of pension regulation is to protect the rights of pension fund members and occupational plan stakeholders (firms and members). Financial prudential regulatory bodies exist in almost all OECD countries (OECD, 2013b).

37. Investment by pension funds should be adequately regulated to ensure solvability (OECD/IOPS, 2011a). The approach should take into account the investment characteristics of the scheme (diversification, maturity and currency matching) given its assets and liabilities. In the case of funded 
defined-benefit plans and DC schemes, the goal of investment strategies is to generate the highest possible returns consistent with the liabilities and liquidity needs of the pension plan.

38. Since the crisis, pension fund investment strategies have become more regulated. Some investment limits on the different asset classes have been put in place. In a large number of OECD countries, pension funds were not constrained in their allocation between bills, bonds and shares (OECD, 2013b). In 2012, restrictions on the allocation of bills and bonds were in place in four OECD countries, while fourteen OECD countries had restrictions on investments in shares.

39. Appropriate calculation methods for the valuation of assets and liabilities, including actuarial techniques and amortisation rules, must be in place to avoid an under-evaluation of the actuarial balance of the scheme. Asset and liability levels are calculated using national (regulatory) valuation methodologies and hence cannot be compared across countries. Differences in methodology are substantial as some countries, like Germany and Spain, use fixed discount rates while others, like the Netherlands and Sweden, use market rates. The liabilities of a pension fund depend on the discount rate, with a lower discount rate increasing pension fund liabilities. Recently, the Netherlands and Sweden announced changes to the methodology for setting the discount rate. Pension funds in the Netherlands will be able to use an ultimate forward rate (UFR) for long maturities as the discount rate, based on long-term assumptions about growth and inflation. In Sweden, the regulator has set a floor on the discount rate (OECD, 2013c).

40. Private occupational plans should be well-funded. While defined-contribution plans should be fully funded, other types of plans should be subject to minimum funding rules or other mechanisms to ensure adequate funding of pension liabilities (OECD, 2010b). The funding ratio requirements should be flexible given the long-term liabilities of pension plans. The funding ratio or activation for additional capitalisation is normally stricter for defined-benefit pension plans. In addition, countries may need to have funding rules that seek to assure that plan assets at least equal all promised benefits to date if the plan were to be terminated/wound-up (the accumulated benefit obligation or termination liability). About $60 \%$ of OECD pension assets are in defined-benefit and other plans, which offer return or benefit guarantees. Pension funds in Portugal, Germany, Sweden and Norway were overfunded in 2010 and 2011 with an average funding ratio around $110 \%$ (Figure 8). In contrast, pension funds were underfunded at the end of 2011 in the Netherlands, Austria and Iceland. For Iceland, the very low funding ratio of 53\% is for public sector pension funds. Since the start of the global financial crisis, the Icelandic government has not made additional contributions to these plans, while the value of assets has declined sharply (OECD, 2013c).

41. The funding standard has an important impact on the investment strategy followed by private pension plans. In particular, for occupational defined-benefit plans, where the liabilities are borne ultimately by the sponsors, clear rules and guidance should be in place to avoid the under-estimation of the liabilities. Prudential ratios require the sponsors to adjust the funding in line with liabilities and the performance of the plans. In defined-benefit plans, the expected investment returns necessary to cover the liabilities of the scheme need to be followed carefully.

42. Guarantee funds are essential to protect members of occupational and private pension plans. In some countries, private and occupational pensions represent an important part of pension income (Ireland, the United States and the United Kingdom, for instance). Moreover, some of the private plans are sponsored by firms or public pension plans and are directly managed by employers. Individuals covered by such pension plans face various risks, such as the risk of the collapse of an enterprise, important losses on investment or underfunding of pension plans.

43. A guarantee mechanism is in place in some countries but to work effectively, these schemes must be independent and have powers to set and collect risk-adjusted premiums (Stewart, 2007). Such mechanisms also need to be complemented by other benefit protection policies (notably effective funding 
rules). For instance, the Pension Benefit Guaranty Corporation (PBGC) in the United States is running deficits since 2002, because it is not independent enough to control the benefits paid or the premiums charged.

Figure 8. Average funding ratio of DB pension plans

Percentage of liabilities in 2010-11

口2011 $\quad$ 口2010

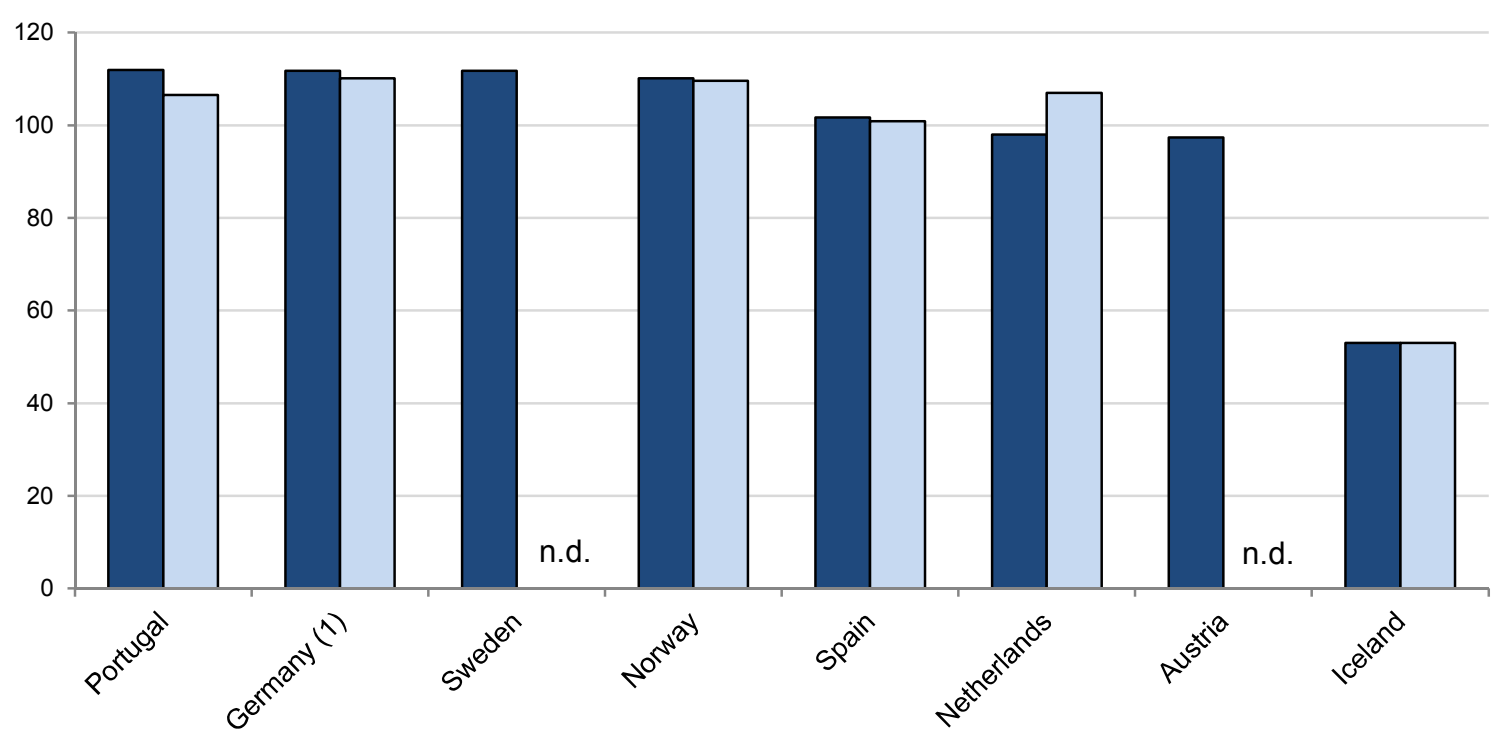

Note: Data are only available for these countries. The average DB funding ratios are regulatory funding ratios directly provided by national pension authorities. n.d. means no data.

1. Data refer to Pensionskassen and Pensionsfonds.

Source: OECD Global Pension Statistics. OECD (2013), Pensions at a Glance 2013: Retirement-Income Systems in OECD and G20 Countries. www.oecd.org/pensions/pensionsataglance.htm.

\section{Protecting pension assets of old workers}

44. Different pay-out options exist in defined-contribution schemes: a life annuity that pays a constant nominal stream of income throughout retirement; an inflation-indexed life annuity where payments are indexed to inflation and are thus constant in real terms; a fixed programmed withdrawal where the assets accumulated at retirement are divided by the life expectancy at retirement; a variable programmed withdrawal where payments vary according to capital gains of the remaining assets and life expectancy at each year in retirement; and, finally, a combined arrangement mixing a variable programmed withdrawal and a deferred inflation indexed life annuity that starts paying at some age (Antolin et al. 2010).

45. In private funded pension schemes, older workers or retired individuals can be disproportionately hit by a reversal of asset returns. Some cohorts may be strongly negatively affected in the short run. Those closest to retirement with pension capital invested in the stock market face the greatest risk in case of a market reversal, as they may begin pension withdrawals before the market can recoup. Retired individuals with a life annuity payment are protected from the stock market shock (the life annuity provider bears the risk). The recent crisis has shown the high exposure of private plans to adverse market movements (Fall et al., 2014) and their consequences on old age living standards. In Ireland, in the aftermath of the crisis, 
workers have lost confidence in the pension system and have consequently reduced their supplementary pension savings.

46. As individuals move closer to retirement or are already in retirement (if their pensions are not annuities) a high proportion of their pension capital should be invested in safer assets even though these investments have lower returns. Investment strategies based on the life-cycle approach are the appropriate default investment strategies. ${ }^{7}$ Life-cycle investment strategies suggest that the amount of assets accumulated to finance retirement allocated to risky assets (e.g. equities) should fall as people get closer to retirement. OECD work using a stochastic model (Antolín et al., 2010) shows that life-cycle strategies provide protection for those close to retirement in the case of a negative shock to the stock market just before retirement.

47. However, the risk-adjusted performance of the different investment strategies depends on the type of benefit during the pay-out phase. Life-cycle investment strategies perform better than, for instance, dynamic investment strategies when benefits are paid as life annuities.

48. Also, in voluntary and occupational private plans, including life insurance, individuals should be encouraged to annuitise their withdrawal from schemes as a protection against longevity risk. Individuals tend to under-estimate the longevity risk and unexpected costs related to ageing. In DC pension plans, individuals bear the longevity risk and only by using the assets accumulated in these plans to buy life annuities can they be insured against longevity risk.

49. However, there are barriers to annuitisation. In particular, life annuities are illiquid and they do not allow for bequests. Also, life annuities are not flexible to allow people to address unexpected shocks requiring important outlays, like health or old age care.

50. Still life annuities present an advantage in providing protection against longevity risk. Therefore, in countries where mandatory DC schemes represent the largest part of the pension system, mandatory annuitisation should be put in place to guarantee that individuals will have an adequate pension during retirement. Some degree of annuitisation of capital accumulated in voluntary DC pension plans, at least as the default arrangement, may also be appropriate.

51. Balancing these various aspects, the OECD (2012) main recommendations are:

- The main recommendation for a default arrangement for the pay-out phase is to combine programmed withdrawals with a deferred life annuity (buying today a life annuity to be paid at a future date). This combination achieves a balance between protection against longevity risk, flexibility, liquidity, possibility of bequests, and investment gains. Programmed withdrawal provides some flexibility and liquidity to face any contingencies, as well as potential portfolio investment gains, and the deferred annuity insures against longevity risk at the cost of only a relatively small portion of the assets accumulated in DC plans.

- The pay-out phase should include protection against inflation. The lack of inflation indexation could reduce the purchasing power of retirement income by as much as one third over a 20 year period, but indexing retirement income to inflation requires a greater saving effort. For example, contribution rates need to increase a little more than 1 percentage point over a 40 -year contribution period to have benefits indexed to inflation, if life expectancy is 20 years at age 65 .

7. Antolín et al. (2010) highlight the value of capital guarantees that protect the nominal value of contributions in DC pension plans. 
52. Partial annuitisation of assets accumulated in DC pension plans only works if there are annuity providers and if annuity markets function well. However, there are many challenges facing annuitisation, from demand and supply constraints in annuity markets. ${ }^{8}$ On the demand side, individuals tend to underestimate their life expectancy and therefore their future demand for protection against the poverty risk in old age. On the supply side, the lack of financial instruments to hedge against longevity risk is one of the factors that explain the lack of enthusiasm by insurers and pension funds to offer life annuity products.

\section{Funding the transition from PAYG to DC schemes}

53. In some OECD countries the financing of PAYG schemes were affected by the introduction of DC schemes. In these countries, the reform of the pension system took the form of a transformation of the PAYG defined-benefit scheme into a funded defined-contribution scheme. Such a transformation implies important transition costs as current liabilities of the PAYG system have to be financed while setting apart funds for the new funded scheme.

54. In the countries that have implemented such a transformation (mainly Eastern European countries), the main issue is whether the new funded scheme is financed through additional pension contributions (a higher burden on the current generation) or by diverting a share of existing contributions from the PAYG scheme to individual accounts in the new funded schemes. Six OECD countries have chosen to substitute part of the PAYG contributions to the new funded DC scheme. Such systems create long-term fiscal gains in terms of lower public pension expenditure at the expense of a short-term revenue shortfall in the PAYG system, with the net actuarial balance depending on the specific design of the schemes (OECD, 2013d).

55. Due to the budget pressures triggered by the crisis, many governments have decided to partially or totally reverse this transformation. In Estonia, for example, contributions to private plans were suspended in 2010, reduced to $2 \%$ in 2011 and returned to $4 \%$ in 2012 . The contributions that were channelled into defined-contribution plans were diverted to the public pension scheme. In Poland, the reversal was partial: the contributions going into individual accounts were cut from $7.3 \%$ to $2.3 \%$ in 2011 and will be optional up to $3.0 \%$ from 2017. In Hungary, the reversal of the systemic reform is complete and all contributions have reverted to the public scheme since 2011. The change is also retroactive. The assets in private pensions were appropriated by the government and all invested contributions were diverted to the PAYG system. In other cases of temporary or partial reversals, balances in existing accounts were left intact (OECD 2013d; Égert, 2012).

56. These experiences show the vulnerability of the pension system to sudden changes. One lesson is that the funding of the transition from PAYG to DC schemes relied too heavily on public financing, which could not be sustained due to the crisis. Also, while implementing DC schemes improves public finances in the long term, in particular when the initial PAYG scheme was too generous, the transition costs can be too important either for the public budget or for working generations.

\section{Policies affecting the adequacy of pensions}

\section{Defining and measuring adequacy}

57. One purpose of pension systems is to allow for consumption smoothing over the life-cycle. The adequacy of pensions can be assessed in different ways:

8. See Mackenzie (2006) for a detailed analysis of annuity markets and pension reforms. 
- Earnings-related adequacy: it is assessed by the pension replacement rate calculated as the share of either life-time earnings or final earnings that the pension benefit replaces. The replacement rate can also be calculated against the average economy-wide earnings. At the individual level, the replacement rate shows the adequacy of the pension level either in comparison with the past or actual consumption level.

- Poverty related adequacy: it is based on the comparison of the pension level with the poverty threshold (proportion of the median income). However, to assess whether retired people are at risk of poverty, one has to take into account all income in retirement and not only pensions. Still, as the pension often constitutes the main, if not the only, income for many retirees, its adequacy is important to avoid old age poverty for most retirees.

- Safety net related adequacy: a low pension level, in particular for retirees with low earnings during their career, implies that people will need to rely on safety-net benefits. Public pension reforms have often resulted in substantial reductions in future benefits. Therefore there is a risk of transferring the ageing cost from pension schemes to social safety net budgets.

58. The outlook for mandatory pension replacement rates shows that adequacy may be an issue in the coming years for some countries (Figure 9). However, taking into account non-mandatory private pension schemes modifies the figure for some countries such as the United States and the United Kingdom.

Figure 9. Net pension replacement rates from public and mandatory private schemes for average earners

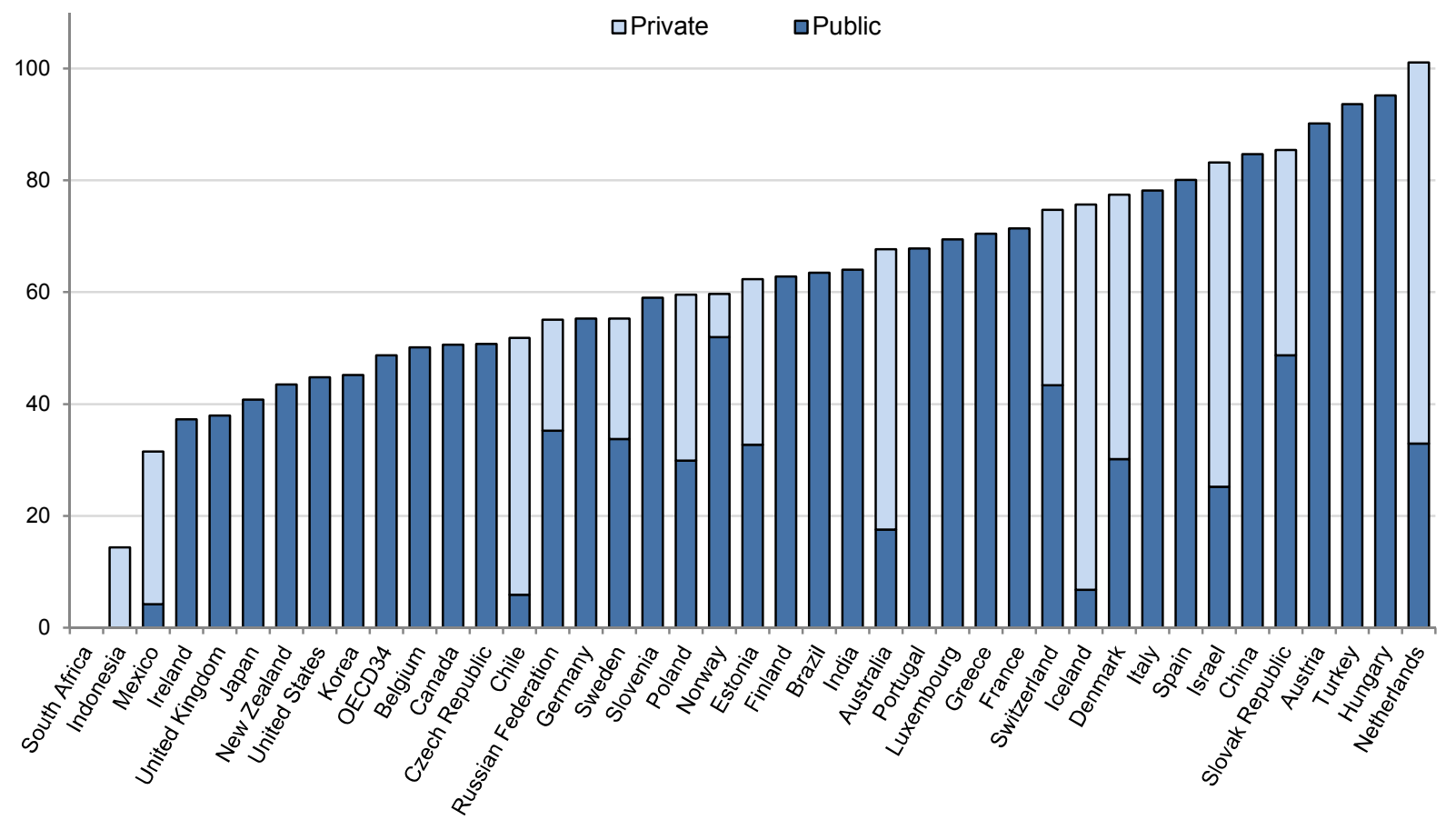

Note: The figure shows net pension replacement rates (i.e. the ratio of pension benefits to earnings after taxes and social security contributions) for full-career workers entering the labour market in 2012 at average earnings. The pension replacement rates are therefore forward-looking and apply to the future entitlements assuming that current pension rules will apply throughout their career until they reach the standard pension age.

Source: OECD (2013), Pensions at a Glance 2013: Retirement-Income Systems in OECD and G20 Countries. www.oecd.org/pensions/pensionsataglance.htm 
59. In some countries, high replacement rates and pension poverty coexist. This is largely due to weak labour market performance over the last 20 years in many countries and, in particular, for low skilled workers. Indeed, a weak labour market performance may generate poor pension entitlements in countries where there is a tight link between contributions and pension benefits. In many countries, public transfers comprising earnings-related pensions and means-tested benefits are the main source of income for pensioners (Figure 10). However, capital returns play an important role in some countries, while in others the elderly have to rely on revenues from work.

Figure 10. Pension income sources of old people

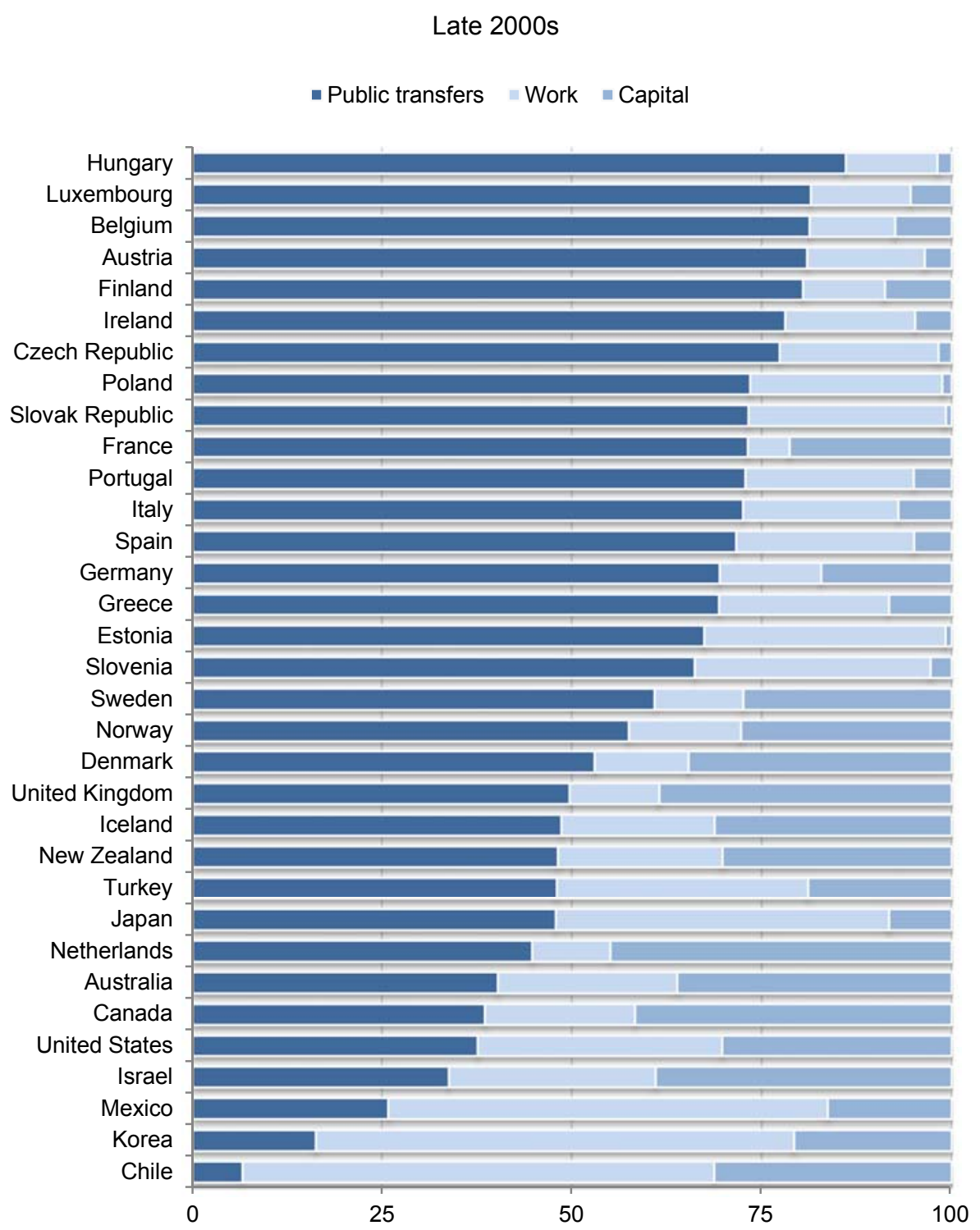

Note: Income from work includes also income from self-employment. Capital income includes private pensions as well as income from the returns on non-pension savings.

Source: OECD Income Distribution and Poverty Database.

60. The adequacy of public transfers can be gauged by the old age poverty rate. On average, $13 \%$ of the over 65 year olds live in income poverty, defined as an income below half the national median 
(Figure 11). In 2010, poverty rates of people aged over 65 were very high in Korea (47\%) and high in Australia (36\%), Mexico (28\%) and Switzerland (22\%). ${ }^{9}$ At below 2\%, Hungary, Luxembourg and the Netherlands had the fewest poor elderly. On average, poverty is higher among older generations $(+75)$ than among younger cohorts of retirees (66-74) due to regressive indexation rules. Korea's very high old-age poverty rate is primarily due to the fact that the public pension scheme was introduced only in 1988, so retirees in the late-2000s had little or no entitlements.

Figure 11. Poverty among older people

\section{0}

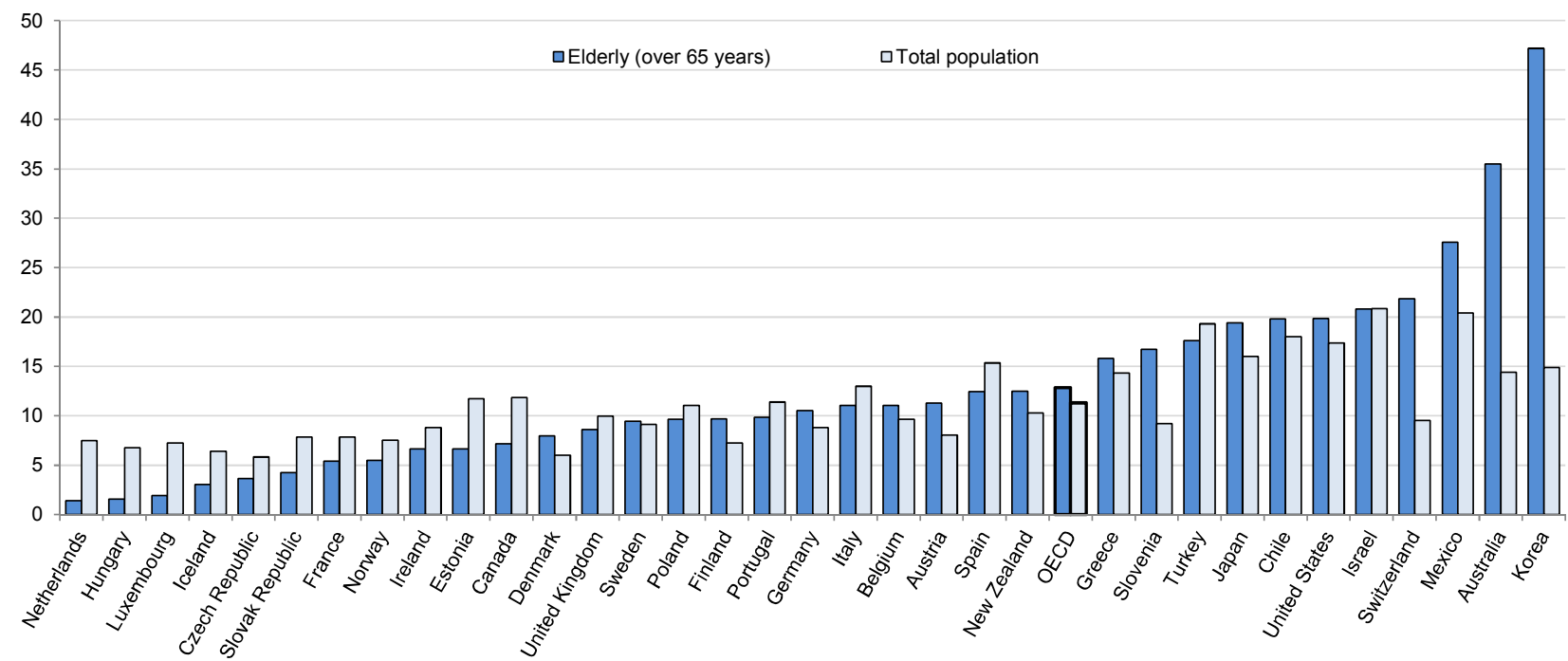

Note: Percentage of people with income of less than $50 \%$ of median household disposable income. Data refer to 2009 for Hungary, Ireland, Japan, New Zealand, Switzerland and Turkey, and to 2011 for Chile.

Source: OECD (2013), Pensions at a Glance 2013: OECD and G20 Indicators; OECD (2013), "Income Distribution", OECD Social and Welfare Statistics (database).

61. Pension coverage of the working-age population is a significant policy concern in some OECD countries. Lower income countries with many workers in the informal sector not enrolled in a pension scheme have a low coverage rate. Only about $60 \%$ of the labour force is covered in Chile and Turkey, and less than 50\% in Mexico (OECD, 2012). This means that many people reach the pensionable age with little or no pension entitlement.

\section{Old age means-tested allowances}

62. Safety net allowances exist in almost all OECD countries to prevent poverty. Old age safety nets are in general means-tested and serve to complement pensions. There are three types of benefits: a noncontributory benefit in 21 countries including the Netherlands and New Zealand, where basic pensions are residency-tested; a targeted safety-net income in 13 countries; and a contributory minimum pension defined as the minimum income of a low-earning, full-career worker. In many countries, there are several programmes and benefits which may be complementary or substitutable.

9. However, for some countries the income poverty measure may overestimate the prevalence of poverty as the elderly may be better off due to the possession of other assets as, for instance, real estate. 
63. In some countries, elderly individuals receive either a non-contributory benefit (basic or targeted benefit) or a minimum pension (Table 2). In Greece, for example, some $60 \%$ of older people are on the contributory minimum pension and a further $19 \%$ on safety-net benefits, with slightly lower proportions for both kinds of schemes in Portugal. Nearly $80 \%$ of Australians receive at least some payment from the resource-tested scheme and nearly $90 \%$ in Denmark. In Finland, France and Sweden, minimum contributory benefits are the most significant, covering $37-47 \%$ of retirees (OECD, 2013c).

Table 2. Coverage of basic, targeted and minimum pensions

\begin{tabular}{|c|c|c|c|c|c|}
\hline & \multicolumn{3}{|c|}{$\begin{array}{l}\text { Relative benefit value } \\
\text { (\% of AW earnings) }\end{array}$} & \multicolumn{2}{|c|}{$\begin{array}{c}\text { Coverage } \\
\text { (\% of over } 65 \text { s receiving) }\end{array}$} \\
\hline & Basic & Targeted & Minimum & Targeted & Minimum \\
\hline Australia & & 28.6 & & 78 & \\
\hline Austria & & 27.9 & & 11 & \\
\hline Belgium & & 25.3 & 28.3 & 5 & 11 \\
\hline Canada & 13.9 & 18.8 & & 34 & \\
\hline Chile & 15.5 & 50.5 & & 60 & \\
\hline Czech Republic & 9.1 & & 12.1 & & n.a. \\
\hline Denmark & 17.5 & 18.1 & & 88 & \\
\hline Estonia & 13.2 & 14.7 & & 6 & \\
\hline Finland & & & 20.6 & & 47 \\
\hline France & & 25.4 & 22.5 & 4 & 37 \\
\hline Germany & & 18.9 & & 2 & \\
\hline Greece & & 13.7 & 36.4 & 19 & 60 \\
\hline Hungary & & & 12.4 & & $<1$ \\
\hline Iceland & 6.5 & 20.4 & & n.a. & \\
\hline Ireland & 36.7 & 34.9 & & 17 & \\
\hline Israel & 14.8 & 28.1 & & 25 & \\
\hline Italy & & 21.6 & 19.3 & 5 & 32 \\
\hline Japan & 16.4 & 20.3 & & 2 & \\
\hline Korea & & 2.9 & & 67 & \\
\hline Luxembourg & 10.2 & 30.8 & 38.9 & 1 & 29 \\
\hline Mexico & & & 27.7 & & n.a. \\
\hline Netherlands & 29.5 & & & & \\
\hline New Zealand & 40.6 & & & & \\
\hline Norway & & & 31.5 & & 22 \\
\hline Poland & & 14.7 & 24.6 & 12 & n.a. \\
\hline Portugal & & 17.4 & 33.8 & 17 & 59 \\
\hline Slovak Republic & & 22.2 & & 3 & \\
\hline Slovenia & & 31.1 & 13.2 & 17 & 2 \\
\hline Spain & & 19.6 & 33.9 & 6 & 28 \\
\hline Sweden & & 14.8 & 24.2 & 1 & 42 \\
\hline Switzerland & & 21.9 & 16.0 & 12 & n.a. \\
\hline Turkey & & 5.2 & 36.8 & & \\
\hline United Kingdom & 15.6 & 19.9 & 10.2 & 27 & n.a. \\
\hline United States & & 17.6 & & 7 & \\
\hline
\end{tabular}

Note: Data are for the most recent year available. n.a.: Data are not available. Blank cells indicate not applicable. The coverage data for Chile and Turkey comprise different programmes.

Source: OECD (2013), Pensions at a Glance 2013: Retirement-Income Systems in OECD and G20 Countries.

64. Incentive effects and adequacy issues arise for the three types of benefits. If non-contributory benefits are too low relative to the poverty threshold, they will increase the poverty rate. In Australia, for example, this benefit was below the poverty threshold in the late-2000s. By contrast, the basic pension in New Zealand was slightly higher than the country's poverty threshold. The incentive issue is related to the "making work pay" principle. Means-tested benefits should provide less revenue than work-based income. In Ireland, for example, the contributory basic pension is worth only slightly more than the resource-tested 
scheme. In Greece, Portugal, Spain, Sweden and Turkey, contributory minimum pensions are set at a significantly higher level than the safety-net income.

65. In many countries, the replacement rate decreases with earnings. Therefore, low income earners with a weak saving capacity have a higher replacement rate during retirement. Specific rules can be set to guarantee that all pensioners with full contribution periods will have a pension level above the poverty line. For instance, in France, the objective of the contributory minimum pension is to guarantee that a pensioner with a full contribution period at full time work at the minimum wage should get a pension corresponding to $85 \%$ of the minimum wage. One issue with such a high replacement rate target is that increases the number of recipients and the financial burden for the scheme. In France, 37\% of pensioners receive the minimum contributory pension.

\section{Public-private mix and extending private pension coverage}

66. The private provision of pensions could be increased in most countries to provide a better diversification of old age income risks and to increase pension adequacy (level and coverage). In many countries old age income is a mix of a national public pension and a private or occupational funded pension. However, in some countries, the national public pension represents a very important share of pension income, thus limiting risk diversification for individuals. A good mix of public and private pensions would allow a better diversification of pension risks between idiosyncratic risks on investments of pension funds and macroeconomic risks to national pension schemes.

67. In 21 OECD countries replacement rates offered by public PAYG pensions to new entrants to the labour force are not expected to reach $60 \%$ for workers on average earnings. Even for low income workers (those with half of the average earnings), there are eleven countries (Australia, Chile, Estonia, Germany, Hungary, Israel, Japan, Mexico, Sweden, Slovak Republic, Poland) for which the replacement rate is expected to fall below $60 \%$ (OECD, 2012). Funded private pensions already play an important complementary role for pension adequacy in Canada, Ireland, the United Kingdom and the United States. Income from capital, predominantly private pensions, accounts for between $25 \%$ of income of over- 65 year olds (Ireland) and 40\% (Canada). The OECD pension gap analysis shows that there are 17 countries with a mandatory pension scheme providing a replacement rate below the average for the 34 OECD countries (Figure 12). Among these countries with a big pension gap, some already have old age poverty rates above the OECD average (Australia, Mexico, the United States, Chile, Japan, Slovenia), illustrating the need to increase coverage of low income earners or workers in the informal sector.

68. Increasing the coverage of private pensions should be a crucial objective in countries where they represent an important complement to (relatively low) public pensions. Increasing coverage can be achieved through 1) compulsion, 2) soft-compulsion via automatic enrolment, and/or 3) improving the existing financial incentives (which should target low income people). Compulsion is the most effective approach to increase the coverage of private pensions (OECD, 2012). Automatic enrolment is a secondbest. Its success in increasing coverage depends on how it is designed and on its interaction with incentives in the system. Among the countries with voluntary private pensions, New Zealand has experienced a substantial increase in coverage thanks to the introduction of automatic enrolment and government subsidies ("KiwiSaver scheme"). 
Figure 12. The pension gap

Gross replacement rate for an average earner from mandatory pension schemes and difference from OECD average replacement rate

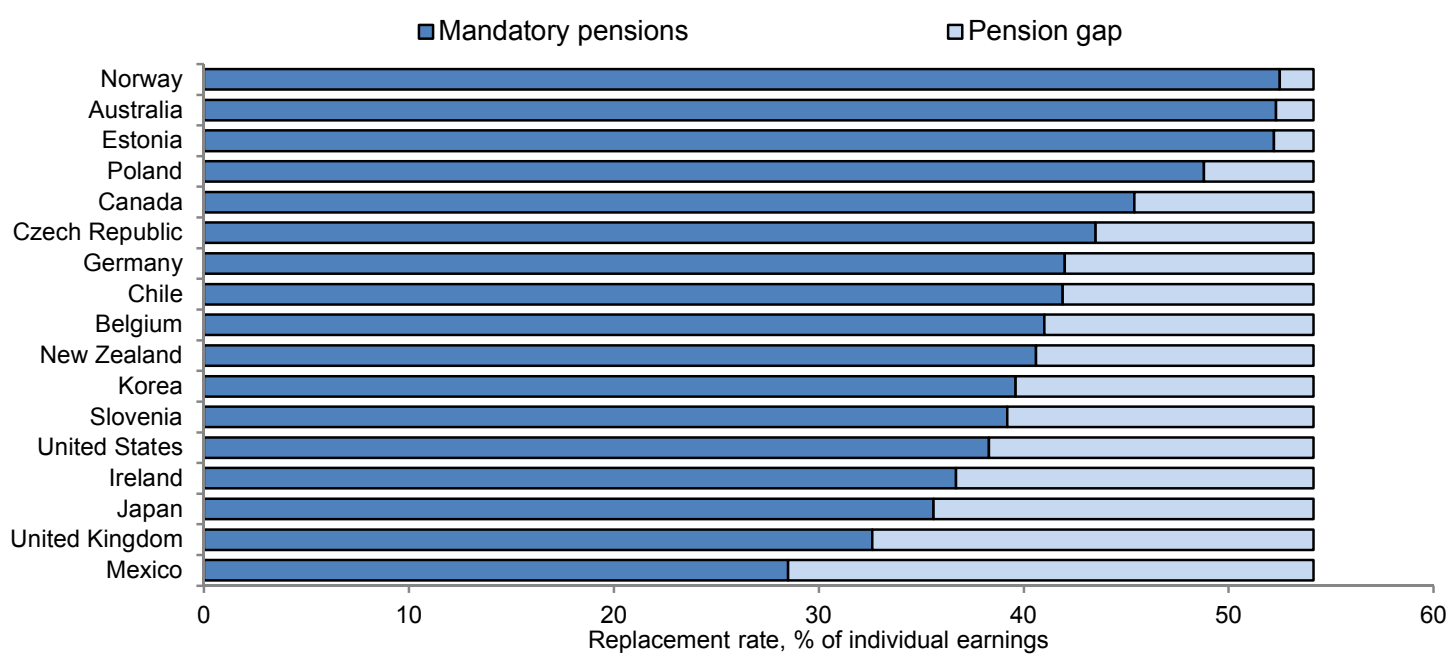

Source: OECD pension models; OECD Earnings Distribution Database. OECD (2013), Pensions at a Glance 2013: RetirementIncome Systems in OECD and G20 Countries. www.oecd.org/pensions/pensionsataglance.htm.

\section{Flanking policies}

\section{Preventing early retirement and exit from the labour market}

69. Increasing the official retirement age has been one prominent feature of pension reforms in almost all countries to cope with ageing. The normal pension age is expected to be at least 65 for all countries (Figure 13). Currently, women can still retire before they are 65 in many countries.

70. However, the effective retirement age is lower than the pensionable age in many OECD countries due to early retirement schemes and distortions to retirement decisions. In order to close the gap between the actual and the statutory retirement age, early retirement is not allowed in eight countries in any mandatory part of the pension system (Denmark, Hungary, Ireland, Israel, the Netherlands, New Zealand, Turkey and the United Kingdom) (OECD, 2013c). In other cases, early retirement is restricted to certain schemes: in Australia, Chile and Iceland to mandatory private pensions; and in Canada and Sweden, there is no early retirement under the basic or targeted programmes.

71. Moreover, in many countries, penalties for early retirement and bonuses for staying beyond the normal retirement age in work exist, which provide an incentive for individuals to work longer. Pensions can go up by $12 \%$ in Portugal for every year of additional work, $10.4 \%$ in the United Kingdom, $8.4 \%$ in Japan and $8 \%$ in the United States for one year of deferred retirement (OECD, 2013c).

72. However, in 19 OECD countries the effective age of labour market exit is lower than the official retirement age for both men and women (Figure 13). The effective age of exit is 7.4 years lower for men in Luxembourg and over five years in both Belgium and France. All three countries have pension systems that permit earlier retirement for people with long careers without a penalty, given a certain number of years of contributions. The figures for women are also highest in these three countries, ranging from 5.0 years in France to 6.3 years in Belgium. 
Figure 13. Average effective age of labour market exit and normal pensionable age
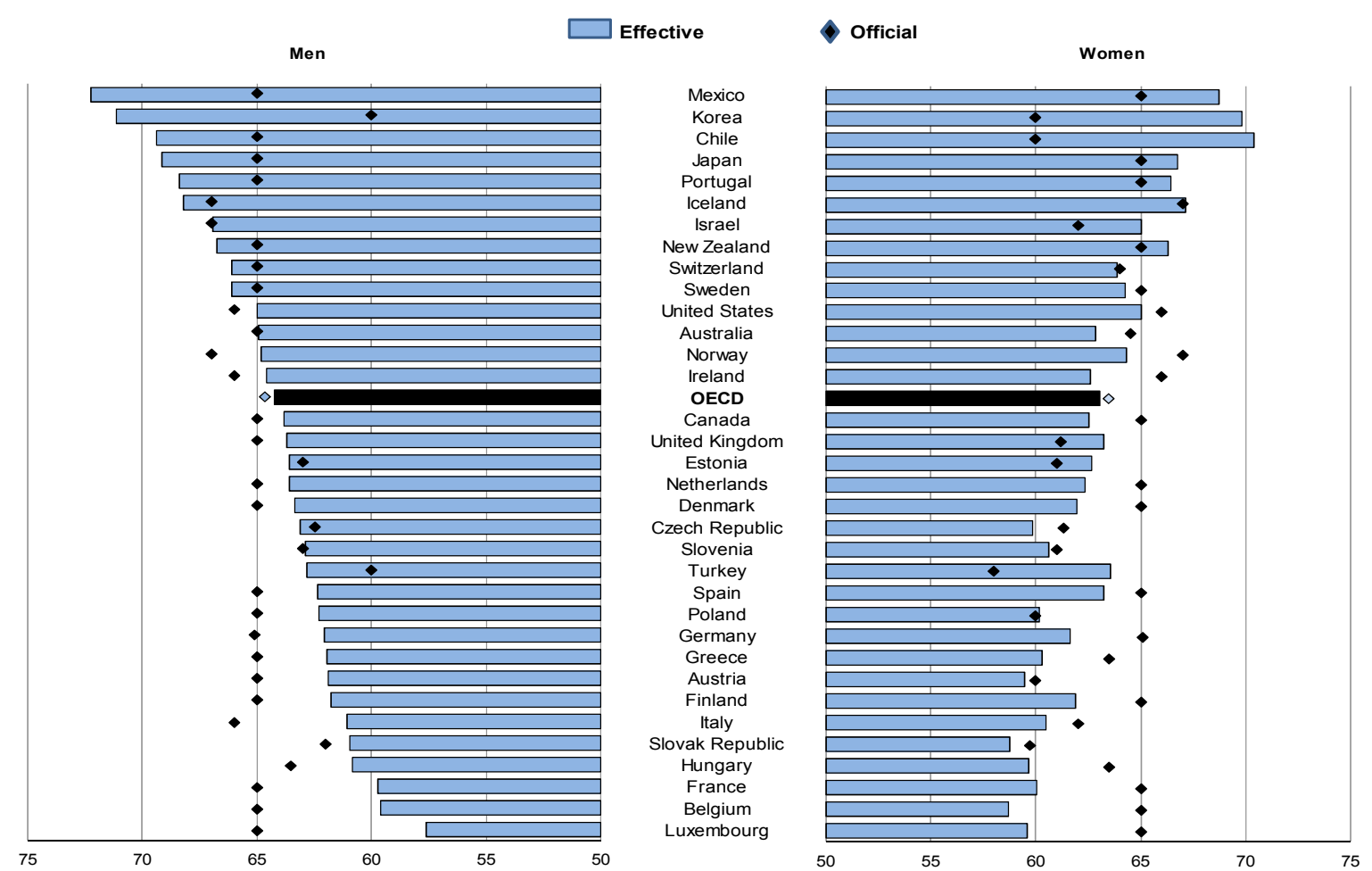

Note: The effective retirement age shown is for the five year period 2007-12; Pensionable age is shown for 2012.

Source: OECD (2013), Pensions at a Glance 2013: Retirement-Income Systems in OECD and G20 Countries.

73. The different pension reforms, the phasing out of early retirement schemes and the tightening of eligibility criteria for other social transfer programmes that operated as de facto early retirement schemes are having an impact on retirement decisions. As a result, the recent performance of older individuals in the labour market has improved. However, reforms are needed to raise the employment of older workers particularly in countries that lag far behind in terms of the labour market exit age (France, Belgium, Luxembourg, Slovak Republic, Italy, Finland, Austria and Greece). Reforms should include a better screening of access to long-term sickness, phasing out of early retirement schemes, changes to the tax on continued work by increasing the increment to pensions for deferred retirement up to the actuarially neutral level, favouring the development of part-time work for older workers and enabling the combination of work with pension receipt.

74. In the face of increasing youth unemployment, one main recommendation by the OECD is to not succumb to the temptation of encouraging older workers to leave the labour force. Rather than promoting early retirement, governments should pursue a strategy that will lead to better employment prospects for both younger and older people, including: i) growth-enhancing structural reforms that have the potential to benefit the labour market outcomes of both young and older workers; ii) targeted active labour market policies to help young and older workers with specific problems of finding or staying in employment; and iii) encouraging employers to adopt a more active stance in managing an age-diverse workforce (OECD, 2013e). 
ECO/WKP(2014)29

\section{Housing policies, homeownership and pension adequacy}

75. Pension adequacy depends also on many other factors affecting the living standard of pensioners. For instance, access to many public services, affordability or coverage of health care and old age long-term care are important for the preservation of living standards. Financial wealth is also a determinant for living standards but it is highly correlated with income in working age.

76. However, living standards at retirement and exposure to poverty risk go beyond the income dimension. Elderly home owners may be less exposed to poverty risk as they do not need cash to pay for rent. However, analysis by the OECD (OECD, 2013c) on the linkages between homeownership, old-age poverty rates and pension level does not allow drawing strong conclusions. Old age poverty seems to be evenly distributed among countries with different levels of homeownership and pension spending. For instance, Australia, Chile, the United States, Iceland and the Slovak Republic show below-average levels of public pension expenditure and above-average rates of homeownership among the elderly, while the poverty rate among the elderly differs substantially across these countries. Still, in some countries, homeownership is low (Austria, Denmark, Germany and the Netherlands) compared to others. But, pensioners in these countries are so far not more exposed to poverty due to a high level of pensions and relatively low rental prices of housing. ${ }^{10}$

77. Pension adequacy should be assessed with regard to housing affordability whether homeownership or rental housing. The demographic ageing contributed positively to the increase in homeownership in OECD countries (Andrews and Caldera Sánchez, 2011). But, homeownership is not distributed uniformly, and is influenced by national housing policies and individual preferences. Homeownership may not be an objective per se, but it matters for pension adequacy in terms of purchasing power when rental prices are high. Therefore housing policies can also be tailored to develop individuals' wealth and assets for retirement (OECD, 2011b).

\section{Policies play an important role in shaping the vulnerability of pension systems}

78. Country profiles have been constructed, which gather the major indicators for sustainability, adequacy and policy levers and compares them with the OECD average. In Figure 14, the dotted line represents the OECD average, the solid line and markers represent the country shown. When the solid line falls outside the OECD average, this implies better results than the OECD average.

79. Figure 14 provides the vulnerability indicators for the Netherlands and the Slovak Republic (see the Appendix for all other OECD countries). The Dutch pension system has two main tiers, consisting of a flat-rate universal (residence-tested) public scheme and earnings-related occupational plans. Although the earnings-related occupational plans are not mandatory, through industrial-relations agreements $91 \%$ of employees are covered. The Slovak Republic's pension system also has two components, a public earnings-related DB scheme and a voluntary defined-contribution pension plan. Participation in the defined-contribution scheme was mandatory for workers entering the labour market for the first time from January 2005; all others had the possibility to choose to join the mixed system or by June 2006 to remain solely in the public scheme. From January 2008 to March 2012, participation in the mixed system has been made voluntary for new entrants to the labour market. The previous changes have modified the system into a default auto enrolment with the possibility to opt out. Auto enrolment rules have come into effect since

10. The analysis in Pensions at a Glance 2013 (OECD, 2013c) cannot fully address the linkages between housing and pension adequacy as the analysis is based on aggregate pension spending and not the distribution of pensions. 
April 2012. Since January 2013, voluntary entrance is possible for new entrants and voluntary entrance is possible before the age of 35 (OECD, 2013c).

80. While the Netherlands' pension system is mainly private, the public and mandatory private components of the Slovak system are complementary for young workers. Both show a replacement rate that is considerably above the OECD average, while the elderly poverty rate is below. The income of the elderly as a per cent of the total population income is somewhat below the OECD average in the Slovak Republic and somewhat above in the Netherlands. The main differences stem from the sustainability indicators. The Slovak Republic has a more favourable future support ratio thanks to a relatively high fertility rate until the 1990s, although projections show a steep drop in the support ratio is expected in the coming decades. The Netherlands' pension system appears to be more sustainable with one of the biggest pension reserve funds (of GDP) and a high return on investment, while the Slovak Republic underperforms in these areas.

81. The retirement age policies in the two countries explain to a large extent the differences between the two countries for public pension spending. The Slovak Republic's official retirement age is one of the lowest in the OECD. The difference in the official retirement age is amplified as the Slovak Republic also has a low effective retirement age. In the Netherlands, both are close to the OECD average.

\section{Figure 14. Comparing vulnerability indicators for the Netherlands and the Slovak Republic Netherlands \\ Slovak Republic}

Policy levers

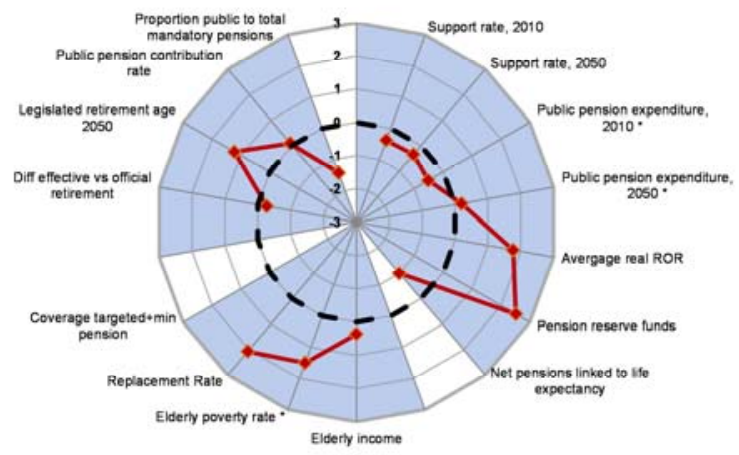

Adequacy
Policy levers Sustainability

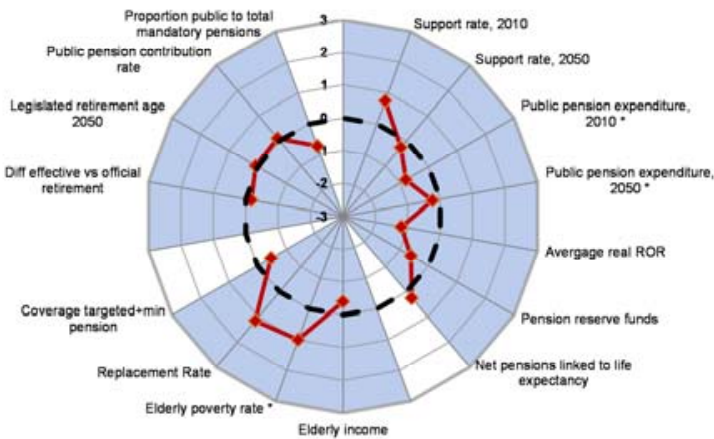

Adequacy

Note: The dotted line represents the OECD average; the solid line represents the country shown. Where the solid line falls inside the OECD average, the variable considered stands below the OECD average. Indicators values are more favourable (e.g. the projected change in expenditure and the poverty gap are lower, while coverage and the contribution rate are higher) the further the observation is away from the centre of the diamond. The indicators are presented in units of standard deviation.

Legend:

Sustainability

Support ratio, 2012 : population aged 20 to 64 as a percentage of those aged 65 and over

Support ratio, 2050 : see above

Public pension expenditure, 2010* : as per cent of GDP (inverted)

Public pension expenditure, 2050* : as per cent of GDP (inverted)

Average real ROR: Average real rate of investment return, in per cent, 2008-11 average

Pension reserve funds : private pensions, in per cent of GDP, 2011

Net pensions linked to life expectancy: as a per cent of total pensions

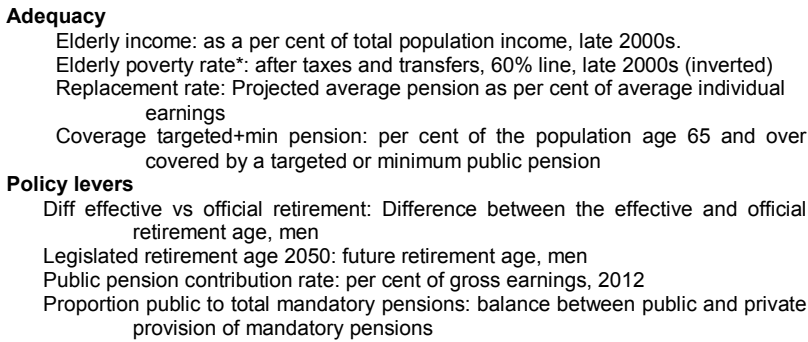

Elderly income: as a per cent of total population income, late 2000s.

Elderly poverty rate*: after taxes and transfers, $60 \%$ line, late 2000 s (inverted) Replacement rate: Projected average pension as per cent of average individual earnings

Coverage targeted+min pension: per cent of the population age 65 and over Policy levers covered by a targeted or minimum public pension

Diff effective vs official retirement: Difference between the effective and official retirement age, men

Legislated retirement age 2050: future retirement age, men

Public pension contribution rate: per cent of gross earnings, 2012

Proportion public to total mandatory pensions: balance between public and private provision of mandatory pensions 


\section{Pension scheme challenges in the BRIICS countries}

82. The BRIICS countries face specific challenges for their pension systems. They need to expand their pension systems, because coverage is low. At the same time their demography is converging rapidly to the OECD average (Figure 15). The main challenges are to set up a comprehensive pension system and to broaden pension coverage in particular for workers in the informal sector. Financial sustainability issues are already present in all the countries due to generous pensions (Brazil), insufficient funding and fragmentation (China), early retirement (Indonesia), carry-over of unfunded past liabilities (India and Russia) and important safety net benefits (South Africa). The importance of the informal sector employing a large number of low income earners is a significant barrier to establishing universal coverage of pension systems.

Figure 15. Support ratio and public pension expenditure in the BRIICS countries

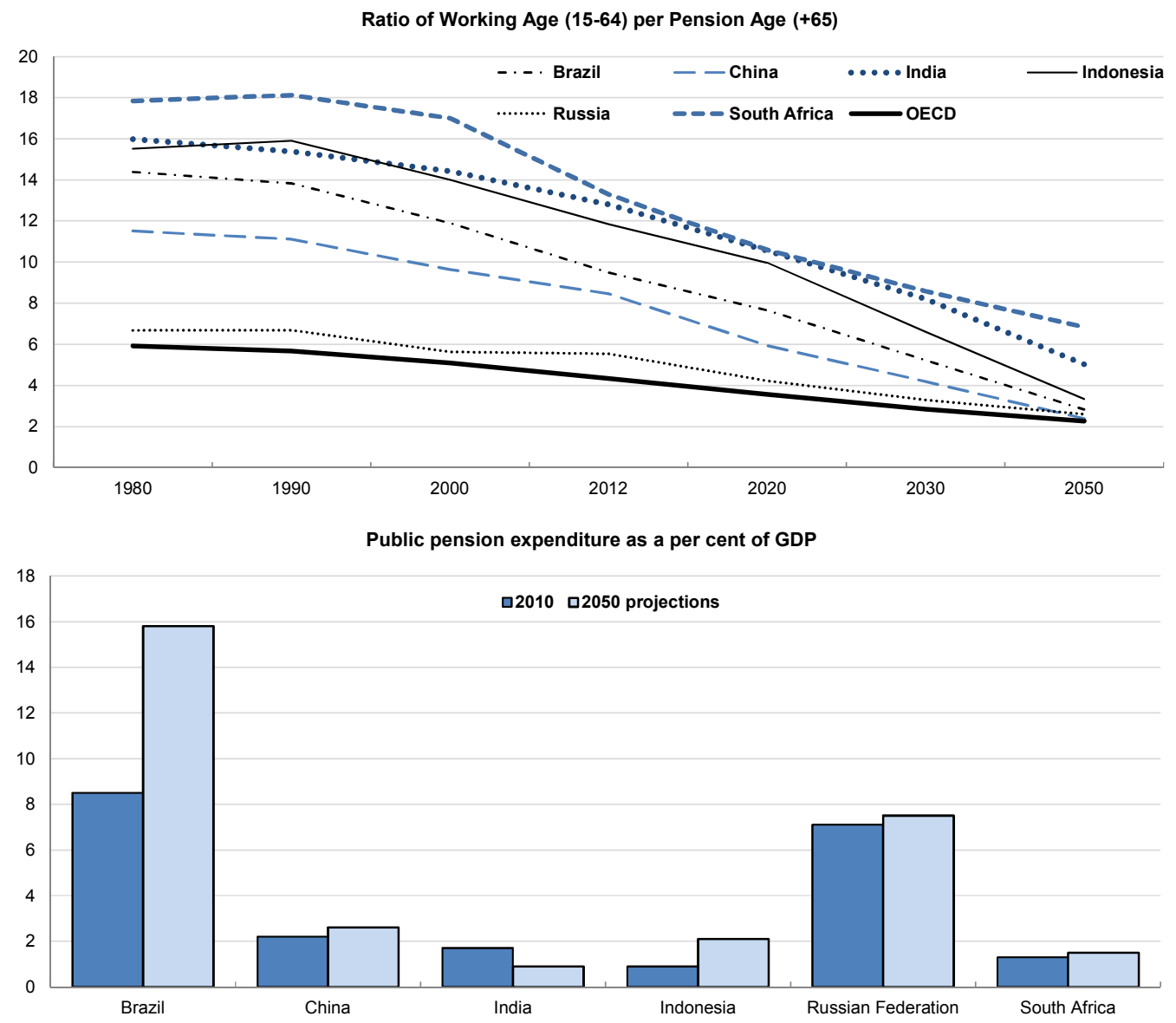

Source: OECD (2013), OECD Pensions at a Glance 2013.

\section{China}

83. China's public pension spending was 3\% of GDP in 2012 (OECD, 2013c). This relatively low level of public pension spending illustrates the youth of the pension system. In the last 15 years, China made important efforts to expand pension coverage. The pension system faces major and urgent challenges. One is the rapid demographic ageing which accentuates the pressure to reform the schemes and another is the decentralised administration. 
84. The Chinese pension system comprises four main schemes. The budget-funded pension scheme for civil servants covers also workers of different institutions with no contributions from insured individuals. The pension scheme for urban workers covers mainly employees of large private enterprises and state-owned enterprises. ${ }^{11}$ Established in 2009, the Voluntary Rural Pension scheme allows rural workers to make contributions into individual accounts that are subsidised by provincial and central governments. The Voluntary Urban Pension scheme that covers non-employed urban residents was put in place in 2011 to expand pension insurance coverage to large parts of urban residents, in particular selfemployed individuals.

85. Rapid ageing heightens the need to ensure the sound financing of the pension system. In most cities, the pension scheme for urban workers is funded through employer (called "social pooling" contributions) and employee contributions. The employer's contributions (20\% of a worker's wage) are pooled together at the local level in order to finance current benefits. This part of the scheme functions as a PAYG defined-benefit scheme. The employee's contributions ( $8 \%$ of the wage) are recorded in an individual account. This part of the scheme was supposed to be funded.

86. However, as the PAYG part is running deficits in many cities and provinces, the authorities have used the funds from individual accounts to pay benefits to current retirees. It is estimated that $90 \%$ of supposedly funded accounts have been used (Zuo, 2013). This is called the problem of "empty accounts" (ISSA, 2013).

87. The problem comes from the insufficient funding of the transition from the past pension system to the new one and lack of resources of local governments. Current cohorts of workers are paying a high contribution rate ( $28 \%$ in total) but the $20 \%$ devoted for paying liabilities to actual retirees is not enough while the $8 \%$ devoted to their pension right accumulation may not be enough to yield an adequate pension level.

88. The difficulties of the pension system are accentuated by the fragmentation of the system and the disparities in income between cities and provinces. Therefore, while some local pension schemes are running large deficits others have surpluses. Indeed, each urban pension scheme is financed and managed by the city or provincial government, often with different rules.

89. This fragmentation within the urban pension schemes is also an impediment to labour mobility. Individuals moving to another city face significant administrative hurdles in transferring their pension rights. The recent guidelines from the central government indicating that individuals retain their pension rights have not yet changed the situation.

\section{India}

90. India's pension system challenges differ from those of the other Asian countries. While most other countries face a challenging demographic trend, the Indian demographics will develop more favourably. The main challenges are to increase pension coverage to workers in the informal sector (pension coverage is only $12 \%$ of the working population) and to ensure the financing of the liabilities of the defined-benefit civil servant schemes (Herd et al., 2010).

91. The pension system covers three main categories of workers: the workers in the formal enterprise sector, the civil servants and the workers in the informal sector. The Employees' Pension Scheme is a

11. Detailed information on this pension scheme, which is the most important one, is available in OECD (2013c), China country sheet. 
defined-benefit scheme but one-third of the capital can be withdrawn as a lump sum. The Employees' Provident Fund Scheme is a defined-contribution scheme with an administered rate of return that provides lump-sum benefits at the time of retirement. Private sector workers have also access to voluntary occupational schemes, called superannuation funds, mainly in the form of defined-contribution plans. The civil servant pension schemes have been reformed in 2003 for new entrants to the civil service since 2004 (those already in service were grandfathered by the old scheme).

92. The pension system for civil servants has been exposed to rapidly rising financial burdens for the government and seems unsustainable in the long run (Swarup, 2013). The central and state governments have to fund or reform these liabilities. For this reason, access to the old schemes was closed for new entrants and replaced by a new pension system.

93. The New Pension System, a defined-contribution scheme, was introduced in 2004 and has since covered new entrants to the central government's civil service. Employers and employees contribute 10\% of the salary and contributions are placed in individual accounts. The minimum retirement age in the new system is 60 years with mandatory annuitisation of $40 \%$ of accumulated capital. While the scheme is designed for central government employees, 27 of the 29 state governments have indicated that they plan to join the scheme. The New Pension System has a targeted replacement rate of $50 \%$ of the final wage.

94. The scheme is mandatory for civil servants, but open to every Indian citizen. Participants have access to two pillars: the first one mandatory for all members is designed to constitute the basic pension and, the second one with more flexible withdrawal policies provides a complementary pension. Tax incentives and co-funding by the government provide incentives for low income earners and individuals in the informal sector to participate.

95. A major challenge for the New Pension System is to broaden the pension coverage to millions of low income people in the informal sector that only have enough revenue for subsistence and to many individuals in remote rural area that lack the well-functioning infrastructure for the collection of contributions and the distribution of pensions.

\section{Indonesia}

96. Indonesia will implement a new pension system in 2015. The design and funding of the new scheme are expected to address the shortcomings of the current system. The main problem with the current system is its inadequacy both in terms of its coverage and ability to provide income for retirement, while an assessment of the implicit liabilities of the current system remains to be done (Muliati, 2013).

97. In the current system, civil servants are covered by a mandatory defined-benefit pension scheme, while private sector workers are covered by a mandatory defined-contribution scheme (Jamsostek) and workers in the informal sector have access to the defined-contribution scheme on a voluntary basis. The main feature of the current scheme is the low coverage; only about $12 \%$ of the labour force is contributing to the scheme. The pension system suffers from the low enforcement of the mandatory registration in the private sector. Only about $25 \%$ of eligible workers are actively contributing to Jamsostek's old age savings programme, indicating high levels of evasion from the mandatory contribution requirement for this programme (Muliati, 2013).

98. Among the factors affecting the financial sustainability of the different pension schemes is the low retirement age. Currently the retirement age varies significantly by type of scheme. The normal retirement age for civil servants is 56 . However, civil servants can retire as early as age 50 with a minimum of 20 years of service. Most private sector employees retire at age 55 but some are eligible for early retirement as early as age 45 . 
99. Adequacy is also an issue. First, the replacement rate for some categories of civil servants is low. In the civil servant pension scheme, the pension is calculated using the final base salary without including bonuses that can constitute the larger part of the total salary leading therefore to a low replacement rate for mid-level to senior officials. Second, in the private sector pension scheme (Jamsostek old age savings programme), the benefit is paid as a lump sum instead of as a monthly annuity leading to low protection against longevity risk. Furthermore, an individual's accumulated capital can be withdrawn before retirement if a worker becomes unemployed, has contributed at least for five years and has been unemployed for six months or more. This further reduces the size of the individual account balance available at retirement. There is therefore a high risk that many individuals will end up with little or no pension income in retirement.

100. To overcome these shortcomings the Indonesian government has decided to implement a new national social security system over the course of the next three years. The first law setting out the principles was voted in 2004 and the second law creating the administrative bodies in charge of the implementation of the new social security system was adopted in 2011. The 2004 law creates a national pension system, including formal and informal sector workers. Formal sector workers and their employers will make contributions as a per cent of wages, informal sector workers will contribute a flat amount and the government will make contributions for the poor that will also be a flat amount.

\section{Brazil}

101. Public pension spending in Brazil reached 8.5\% of GDP in 2010. It is the highest level of pension spending among the BRIICS countries and is close to the OECD average of $9.3 \%$ in $2010 .{ }^{12}$ The drivers of this high level of expenditures are the ageing dynamics and the generosity of the pension system.

102. Brazil has a complex pension system. The Regime General de Previdência Social (RGPS), covers the private sector workforce. It is financed by payroll taxes, revenues from sales taxes and federal transfers that cover revenue shortfalls of the system. It is a mandatory pay-as-you-go scheme operated by the National Social Security Institute (NSSI). The NSSI also operates some state and municipal pension schemes (ISSA, 2013). Federal civil servants are covered by the Statutory Social Security Regimes for Civil Servants. On top of these mandatory schemes, there are many occupational pension schemes and private pension plans.

103. In the past 20 years, the government took many initiatives to broaden pension coverage to rural areas, agricultural workers and individuals in the informal sector. But, most important is the use of pensions as an anti-poverty instrument. Universal coverage has almost been achieved for older individuals through an overlapping between contributory pension coverage and non-contributory allowances (meanstested benefits, such as Bolsa Familial and other conditional cash transfer programmes). To prevent pensioners' incomes from falling behind the rest of the population, the minimum pension benefit payable by the social security system is linked to the federal minimum wage (OECD, 2013f). This is one of the major drivers of pension spending as upward revisions to the minimum wage translate into higher pension spending.

104. The survival and disability pension rules are also generous. Lifetime survivors' benefits are provided without regard to the age of the spouse, number of children in the family, or length of the marriage. Therefore, adult workers can receive a life time survival pension without conditions. Disability pensions benefit a large number of individuals and are based on loose criteria. Between 2005 and 2010, disability and survival pensions comprised $34.8 \%$ of pension expenditure (ISSA, 2013).

12. The average is calculated for the 28 OECD countries, for which data are available (OECD, 2013c). 
105. The Brazilian pension system is facing several challenges. The most important is to ensure the long-term financial sustainability of the pension system. Even the contributory general regime for workers is expected to run deficits in the future. In terms of coverage, there is a wide discrepancy between almost universal benefit provision and the low number of contributors. Indeed, about $50 \%$ of the working population, including rural workers, domestic employees, and workers in the informal urban economy, generally do not contribute regularly. This discrepancy adds to the reliance of the pension systems on central government funding.

\section{Russian Federation}

106. Russia undertook an important reform of its pension system in 2002. The changes transformed the pay-as-you-go defined-benefit system to a mixed system that consists of both pay-as-you-go and defined-contribution schemes. However, the pension system still faces important financial sustainability challenges partly due to the carry-over of past liabilities and the increase in pension levels to address old age poverty.

107. The compulsory pension system has three components: a basic pension, an insurance benefit based on a notional defined-contribution (NDC) account and a funded defined-contribution scheme. The basic pension was incorporated into the insurance part of the earnings-related pension in 2010 (OECD, 2013d). It is a flat rate pension provided to all those with a minimum of five years of contributions. Since most of those currently retiring worked in Soviet times, almost all current retirees receive this pension.

108. Since 2010, the basic pension has been financed through insurance contributions for the mandatory pension insurance. The contribution rate channelled to the basic pension has declined from $14 \%$ in 2005 to $6 \%$ in 2009 for those born in 1967 or later. This contribution is since then consolidated with that of the notional defined-contribution schemes (OECD, 2013d).

109. The second part of the pension is an earnings-related plan designed as a notional definedcontribution (NDC) scheme. At retirement, the accumulated contributions in an individual's account are annuitised using a factor based on life expectancy.

110. The third part of the pension system is the mandatory funded DC scheme. In 2010, Russia introduced a system of co-financing or matching additional contributions from the state to the mandatory funded pension system. The state subsidy can therefore be an important tool to promote higher retirement savings and therefore improve future adequacy of retirement income.

111. Pension levels, in particular basic pensions, have been increased sharply to address a growing problem of old-age poverty. In 2009 and 2010, the average social pension payment increased to a level just above the social minimum income. Average pension payments at the beginning of 2008 were worth just over $20 \%$ of average earnings, but by the beginning of 2010 , the average pension had almost doubled to just below $40 \%$ of average earnings (OECD, 2013d).

112. The Russian pension system is generous, posing sustainability problems. Under the pension entitlement rules in 2012, a person receiving average earnings working from age 20 to the pensionable age of 60 would receive a gross replacement rate (pension relative to individual earnings) of about $60 \%$ (OECD, 2013c). For a worker on average earnings, the total net replacement rate from the mandatory system would be close to $70 \%$, which is above the OECD average.

113. The Russian pension system is already under financial pressure despite high contribution rates. The financing of the pension system relies heavily on budget transfers. The financing problem has become worse over the years. The share of general budget financing of pensions has increased from $24 \%$ of total pension expenditure in 2007 to $46 \%$ in 2011 . At $9.2 \%$ of GDP in 2012, Russian public pension expenditure 
is already above the OECD average and has increased rapidly in recent years, from a level of $5.1 \%$ in 2007.

114. The financial problem stems from a classical transition difficulty from an unfunded PAYG scheme to a funded DC scheme. In the short run, contributions to the PAYG scheme are diverted to fund the DC scheme. But, benefits earned through the past PAYG scheme have to be financed. To circumvent the financing difficulties, the new legislation reduces the part of the contributions devoted to the funded scheme in favour of the NDC scheme. The contribution rate for those persons who have their contributions invested in the national pension fund will be reduced to $2 \%$ from their current $6 \%$. The difference (4\%) will be paid into their NDC account instead.

\section{South Africa}

115. South Africa does not have a public contributory pension scheme, nor is there any statutory duty to belong to private funds. However, there is a universal means-tested old age pension covering $75 \%$ of those above 60 years. The extension of the old-age pension grant has been used as a tool to alleviate poverty among old aged individuals and children through kinship housing. Although the population dynamics of South Africa is still favourable, there is a need for comprehensive reform of the pension system.

116. The old-age grant provided by the government is the main source of income for $75 \%$ of the elderly population in retirement. About three quarters of the population reach retirement age without a funded pension benefit.

117. Workers have access to occupational pension plans. These pension funds are mainly financed through employer and employee contributions and therefore the access is limited to individuals in the formal sector. The majority of employees in the private sector are covered by defined-contribution schemes while those in the public sector largely enjoy coverage by defined-benefit arrangements. Persons engaged in the informal sector are to a large extent excluded from the contributory retirement schemes. Although there are private insurance products offered by commercial insurers, they are largely unaffordable for informal-sector workers.

118. Due to low coverage of the occupational scheme, the often limited duration of contributions or early withdrawals of accumulated contributions, the adequacy of the overall pension system is considered unsatisfactory. The government has proposed a social security and retirement reform. The key objective is to set up a pension system including people with insufficient income or who are engaged in informal activities. 
ECO/WKP(2014)29

\section{BIBLIOGRAPHY}

D'Addio, A. C., J. Seisdedos and E. R. Whitehouse (2009), "Investment Risk and Pensions: Measuring Uncertainty in Returns", OECD Social, Employment and Migration Working Papers, No. 70, OECD Publishing, Paris. doi: $10.1787 / 224016838064$

Andrews, D. and A. Caldera Sánchez (2011), "Drivers of Homeownership Rates in Selected OECD Countries", OECD Economics Department Working Papers, No. 849, OECD Publishing, Paris. doi: $10.1787 / 5 \mathrm{kgg} 9 \mathrm{mcwc} 7 \mathrm{jf}$-en

Antolín, P. (2007), "Longevity Risk and Private Pensions", OECD Working Papers on Insurance and Private Pensions, No. 3, OECD Publishing, Paris. doi: $10.1787 / 261260613084$

Antolin, P. S. Payet and J. Yermo (2010), “Assessing Default Investment Strategies in Defined Contribution Pension Plans”, OECD Journal: Financial Market Trends, Vol. 2010/1. doi: 10.1787/fmt-2010-5km7k9tp4bhb

Barr, N. and P. Diamond (2011), “Improving Sweden's Automatic Pension Adjustment Mechanism”, Issue in Brief, No. 11-2, Center for Retirement Research at Boston College.

Curristine, T., J. Harris and J. Seiwald (2013), "Case Studies of Fiscal Council - Functions and Impact", IMF Policy Paper, July 2013.

Égert, B. (2012), "The Impact of Changes in Second Pension Pillars on Public Finances in Central and Eastern Europe", OECD Economics Department Working Papers, No. 942, OECD Publishing, Paris.

doi: $10.1787 / 5 \mathrm{k} 9$ fltdtxbr6-en

Fall, F. (2014), "A Framework of Comparing the Robustness of PAYG Pension Schemes”, OECD Economics Department Working Papers, No. 1134, OECD Publishing, Paris.

Fall, F. and N. Ferrari (2008), "The Outlook for Pension Spending and the Role of a Reserve Fund", Tresor-Economics, No. 39.

Fall, F. et al. (2014), "Vulnerability of Social Institutions: Lessons from the Recent Crisis and Historical Episodes", OECD Economics Department Working Papers, No. 1130, OECD Publishing, Paris.

Hagemann, R. (2011), "How Can Fiscal Councils Strengthen Fiscal Performance?", OECD Journal: Economic Studies, Vol. 2011/1, OECD Publishing, Paris.

doi: 10.1787/eco_studies-2011-5kg2d3gx4d5c

Herd, R., H. Hu and V. Koen (2010), "Providing Greater Old-Age Security in China", OECD Economics Department Working Papers, No. 750, OECD Publishing, Paris.

doi: $10.1787 / 5 \mathrm{kmlh} 4 \times 7 \mathrm{pc} 7 \mathrm{k}$-en 
IMF (International Monetary Fund) (2012), "Chapter 4: The Financial Impact of Longevity Risk" in Global Financial Stability Report, April 2012, Washington DC.

ISSA (International Social Security Association) (2013), Social Security Coverage Extension in the BRICS: A Comparative Study on the Extension of Coverage in Brazil, the Russian Federation, India, China and South Africa, International Social Security Association, Geneva, available at www.issa.int/Resources/Resources/Social-security-coverage-extension-in-the-BRICS-Acomparative-study-on-the-extension-of-coverage-in-Brazil-the-Russian-Federation-India-China-andSouth-Africa.

Mackenzie, G. A. (2006), “Annuity Markets and Pension Reform”, Cambridge University Press, Cambridge.

Muliati, I. (2013), "Pension Reform Experience in Indonesia", World Bank, prepared for IMF conference "Designing Sustainable and Equitable Pension Systems in Asia in the Post Crisis World", www.imf.org/external/np/seminars/eng/2013/oapfad/pdf/muliati_ppr.pdf.

OECD (2009), Pensions at a Glance 2009: Retirement-Income Systems in OECD Countries, OECD Publishing, Paris.

doi: 10.1787/pension_glance-2009-en

OECD (2010a), "Making Reform Happen, Lessons from OECD Countries”, OECD Publishing, Paris. doi: $10.1787 / 9789264086296$-en

OECD (2010b), OECD Principles of Occupational Pension Regulation: Methodology for Assessment and Implementation, OECD Publishing, Paris.

doi: $10.1787 / 9789264087095$-en

OECD (2011a), OECD/IOPS Good Practices for Pension Funds' Risk Management Systems, OECD Publishing, Paris. www.oecd.org/site/iops/principlesandguidelines/46864307.pdf.

OECD (2011b), Economic Policy Reforms 2011: Going for Growth, OECD Publishing, Paris. doi: 10.1787/growth-2011-en

OECD (2012), OECD Pensions Outlook 2012, OECD Publishing, Paris doi: 10.1787/9789264169401-en.

OECD (2013a), Pension Markets in Focus, OECD Publishing, Paris. www.oecd.org/finance/PensionMarketsInFocus2013.pdf

OECD (2013b), Annual Survey of Investment Regulations of Pension Funds OECD Publishing, Paris, www.oecd.org/daf/fin/private-pensions/InvRegPensionFunds2013.pdf.

OECD (2013c), Pensions at a Glance 2013: OECD and G20 Indicators, OECD Publishing, Paris. doi: 10.1787/pension_glance-2013-en

OECD (2013d), "Developing a Funded Pension System in Russia: International Evidence and Recommendations", OECD Publishing, Paris. www.oecd.org/pensions/RussaFundedPensionSystem2013.pdf

OECD (2013e), OECD Employment Outlook 2013, OECD Publishing, Paris. doi: 10.1787/empl_outlook-2013-en 
OECD (2013f), OECD Economic Surveys: Brazil 2013, OECD Publishing, Paris. doi: 10.1787/eco_surveys-bra-2013-en

Queisser, M. and E.R. Whitehouse (2006), "Neutral or Fair? Actuarial Concepts and Pension-System Design”, OECD Social, Employment and Migration Working Papers, No. 40, OECD Publishing, Paris.

doi: $10.1787 / 351382456457$

Stewart, F. (2007), "Benefit Security Pension Fund Guarantee Schemes", OECD Working Papers on Insurance and Private Pensions, No. 5, OECD Publishing, Paris.

Swarup, D. (2013) "The Reform Experience of India: Widening Coverage in a Sustainable and Equitable Way", prepared for IMF Conference, "Designing Sustainable and Equitable Pension Systems in Asia in the Post Crisis World", www.imf.org/external/np/seminars/eng/2013/oapfad/pdf/swarup_ppr.pdf

Tompson, W. (2009), The Political Economy of Reform: Lessons from Pensions, Product Markets and Labour Markets in Ten OECD Countries, OECD Publishing, Paris. doi: 10.1787/9789264073111-en

Zuo, X. (2013), "Designing Fiscally Sustainable and Equitable Pension Systems in China," presentation at IMF conference, "Designing Sustainable and Equitable Pension Systems in Asia in the Post Crisis World", 9-10 January 2013, Tokyo.

www.imf.org/external/np/seminars/eng/2013/oapfad/pdf/zuo.pdf. 
APPENDIX 1

Australia

Figure A1. Pension system vulnerability indicators

Policy levers

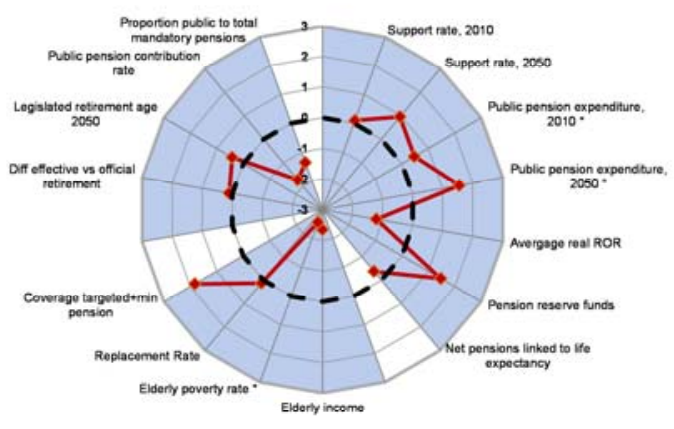

Adequacy

Belgium

Policy levers

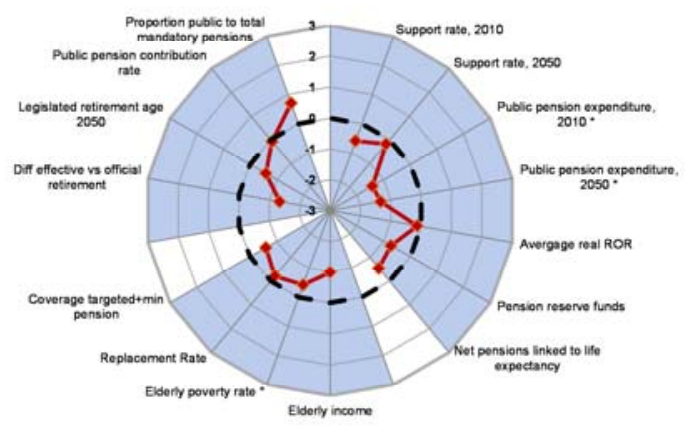

Adequacy

Chile

Policy levers

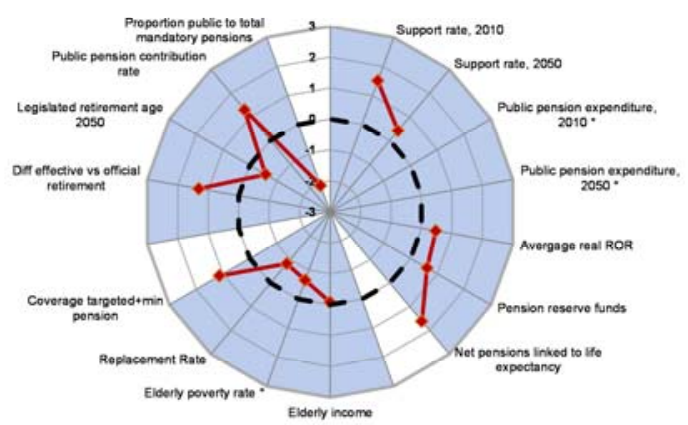

Adequacy
Austria

$\begin{array}{ll}\text { Policy levers } & \text { Sustainability }\end{array}$

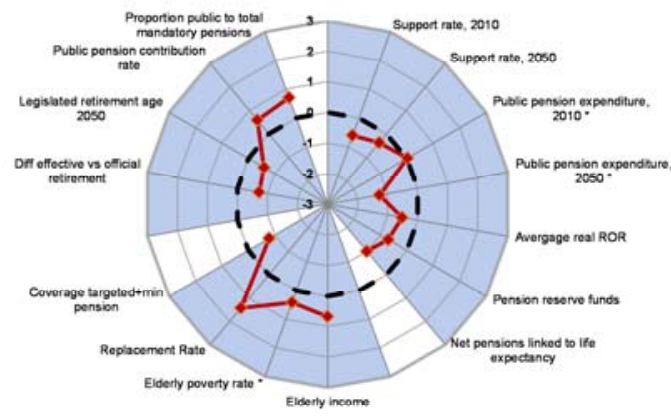

Adequacy

\section{Canada}

$$
\text { Policy levers } \quad \text { Sustainability }
$$

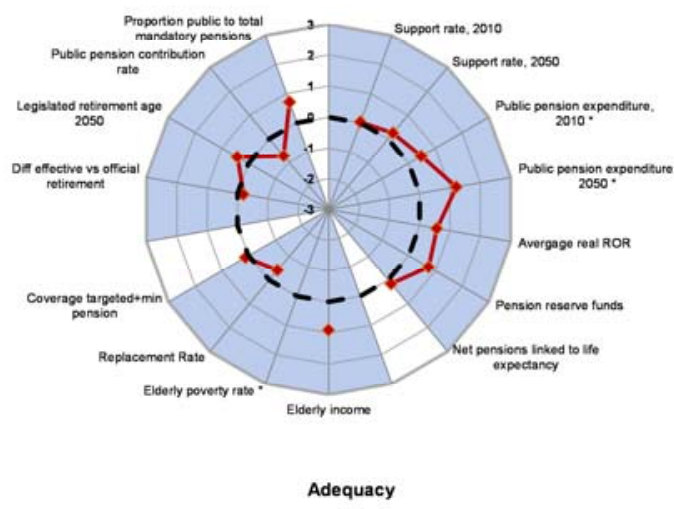

Czech Republic

Policy levers Sustainability

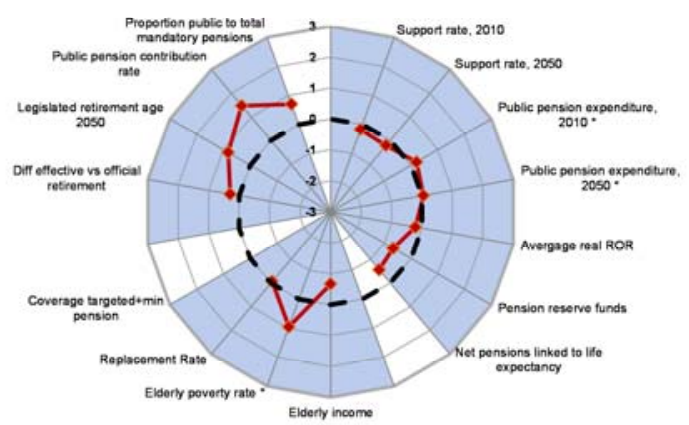

Adequacy 
Pension system vulnerability indicators (cont.)

Denmark

Policy levers

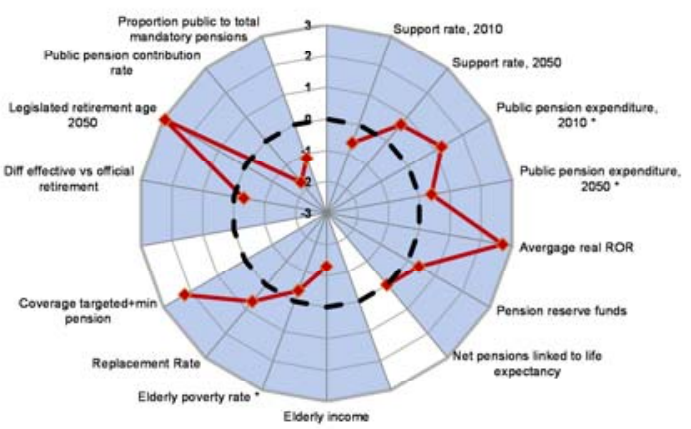

Adequacy

Finland

Policy levers

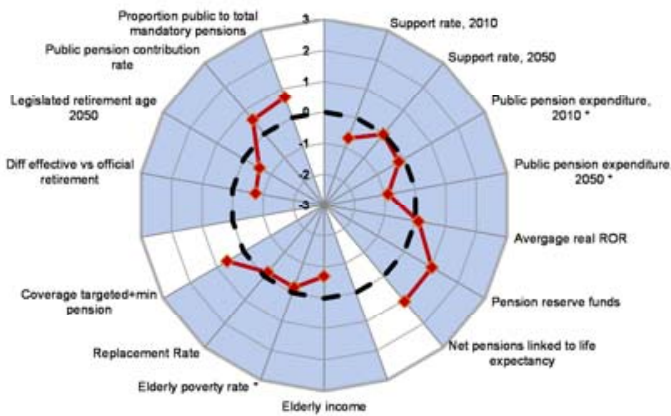

Adequacy

Germany

Policy levers

Sustainability

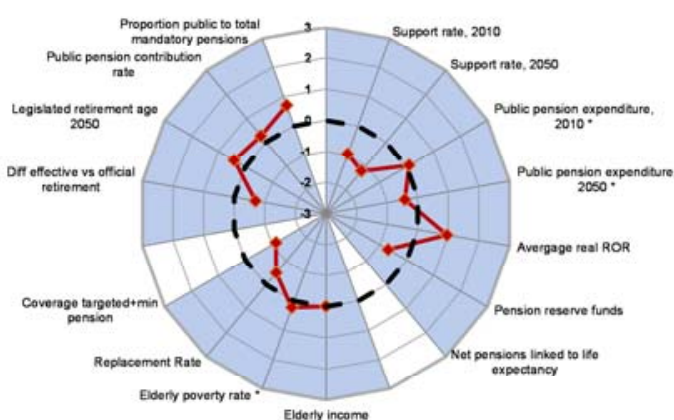

Adequacy
Estonia

\author{
Policy levers \\ Sustainability
}

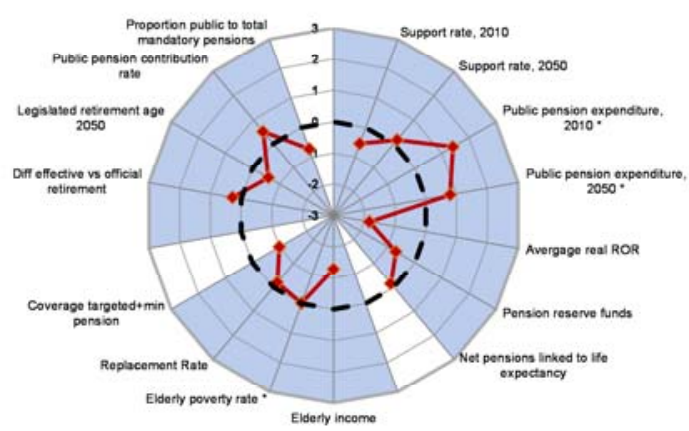

Adequacy

France

\begin{tabular}{ll} 
Policy levers $\quad$ Sustainability \\
\hline
\end{tabular}

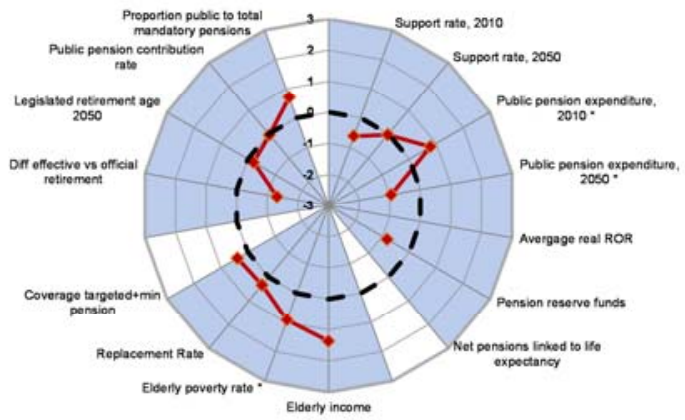

Adequacy

Greece

$\begin{array}{ll}\text { Policy levers } & \text { Sustainability }\end{array}$

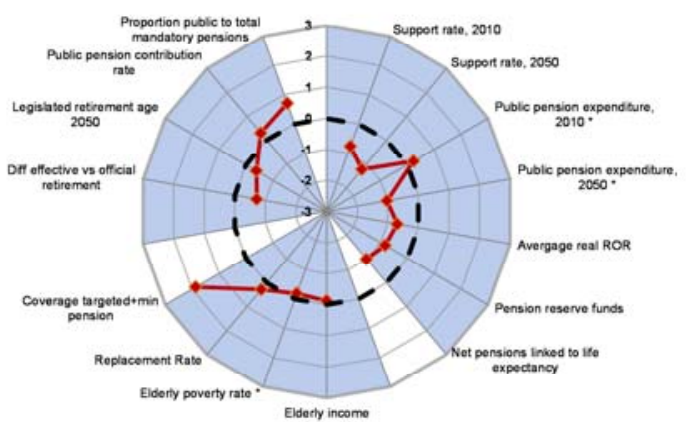

Adequacy 
Policy levers

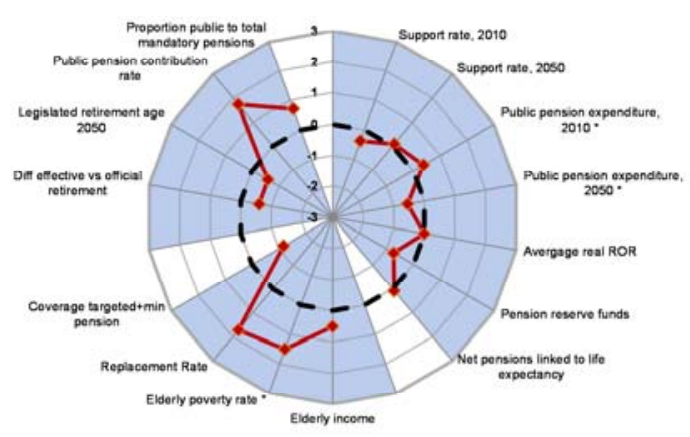

Adequacy

Ireland

Policy levers

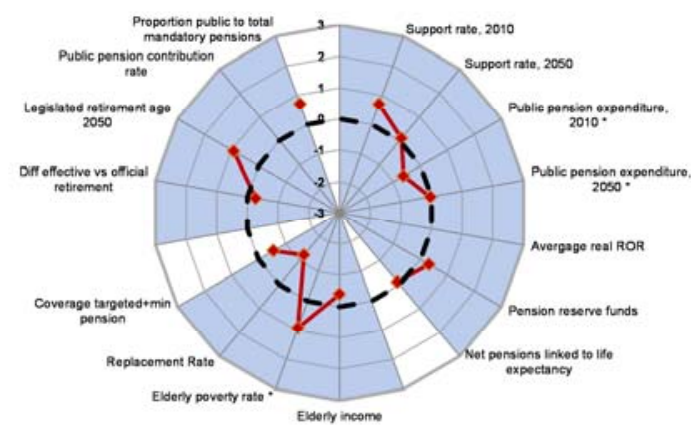

Adequacy

Italy

Policy levers

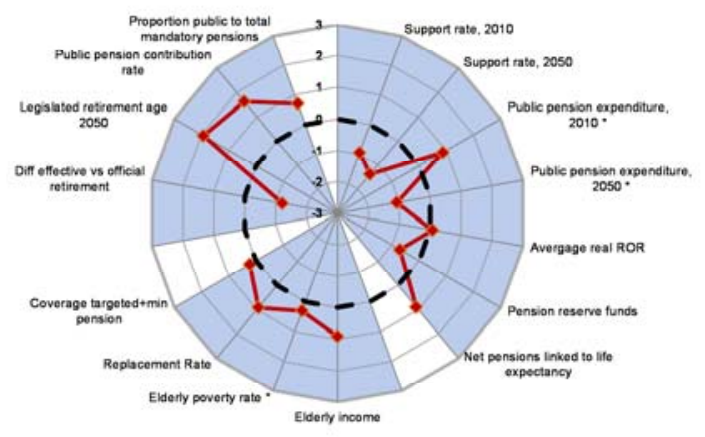

Adequacy
Policy levers $\quad$ Sustainability

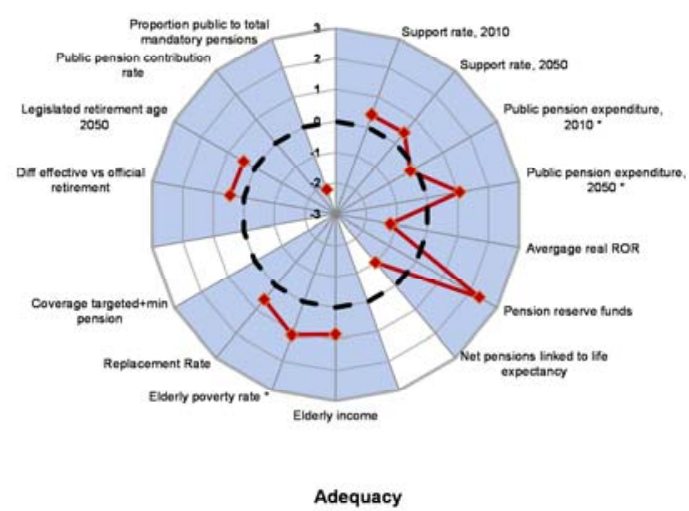

Israel

Policy levers

Sustainability

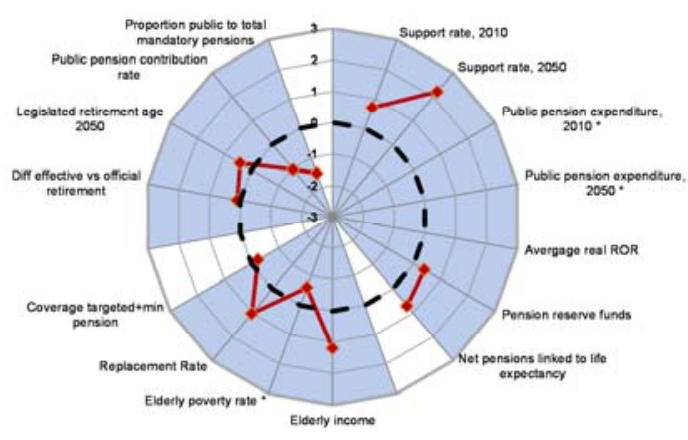

Adequacy

Japan

Policy levers

Sustainability

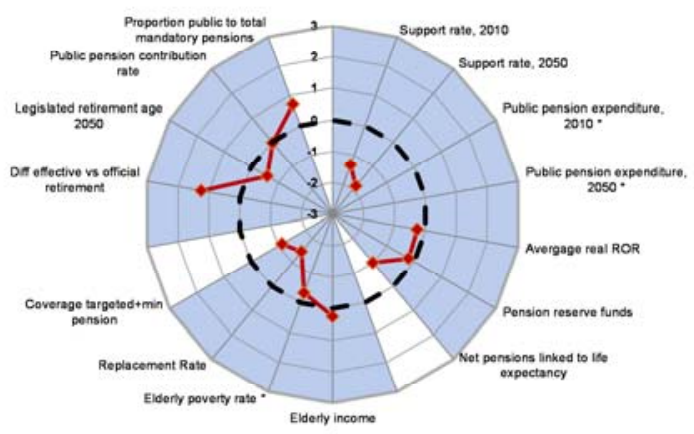

Adequacy 
Pension system vulnerability indicators (cont.)

Luxembourg

Policy levers

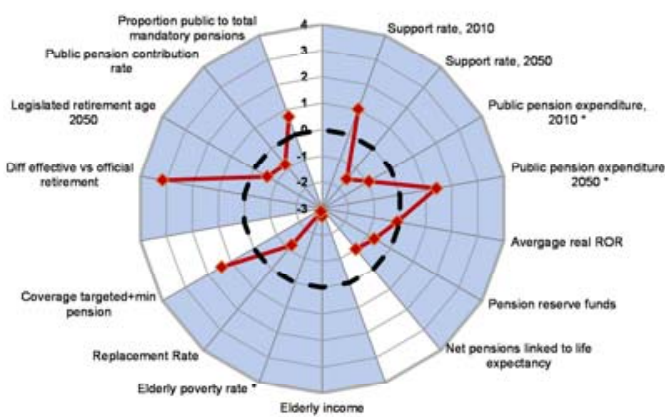

Adequacy

Mexico

Policy levers

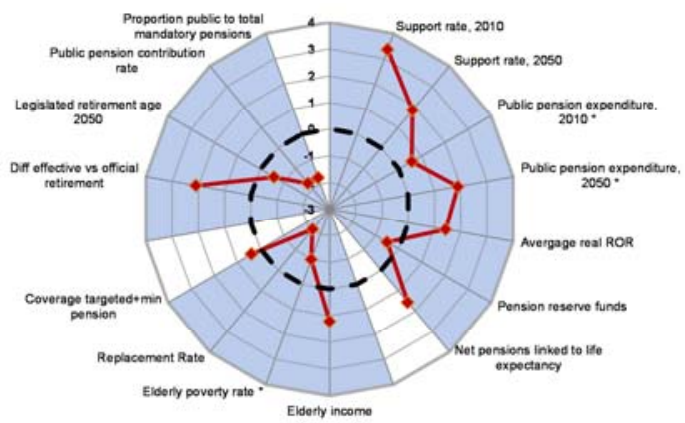

Adequacy

New Zealand

Policy levers

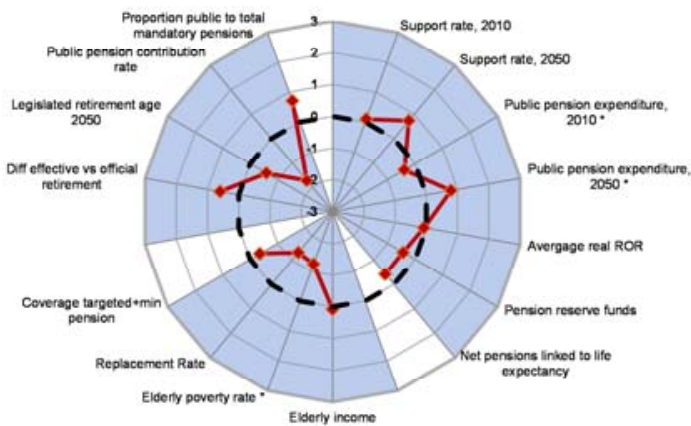

Adequacy
Policy levers

Sustainability

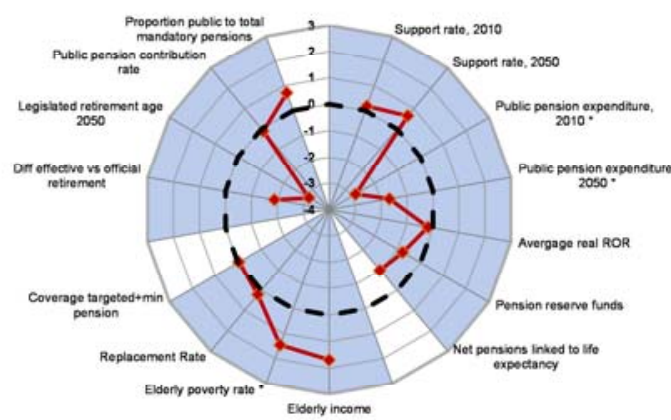

Adequacy

Netherlands

Policy levers

Sustainability

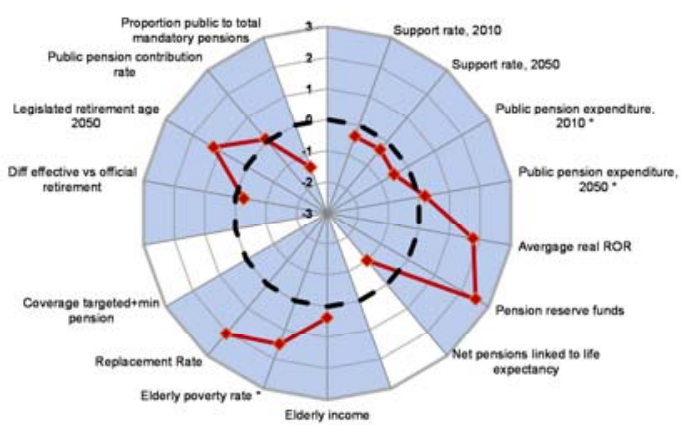

Adequacy

Norway

Policy levers

Sustainability

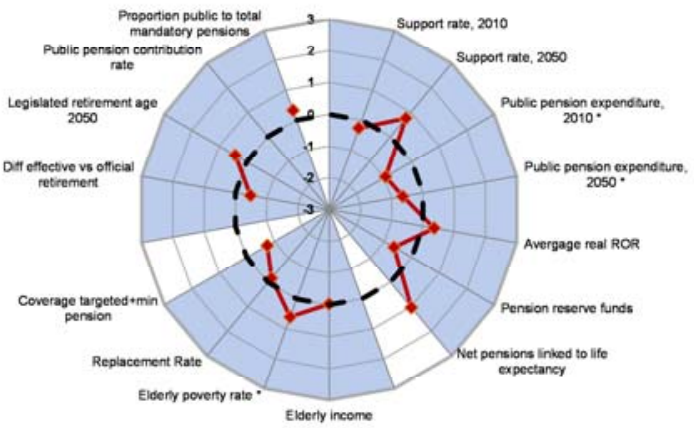

Adequacy 
Pension system vulnerability indicators (cont.)

Policy levers

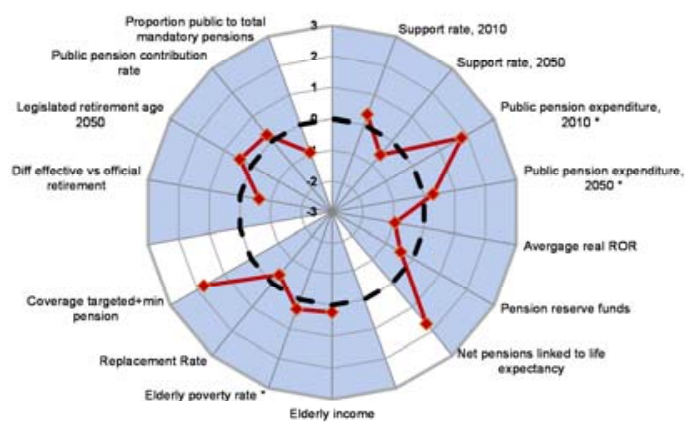

Adequacy

Slovak Republic

Policy levers

Sustainability

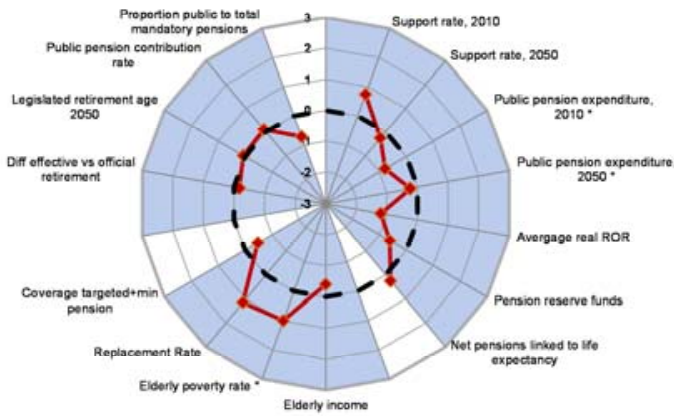

Adequacy

Spain

Policy levers

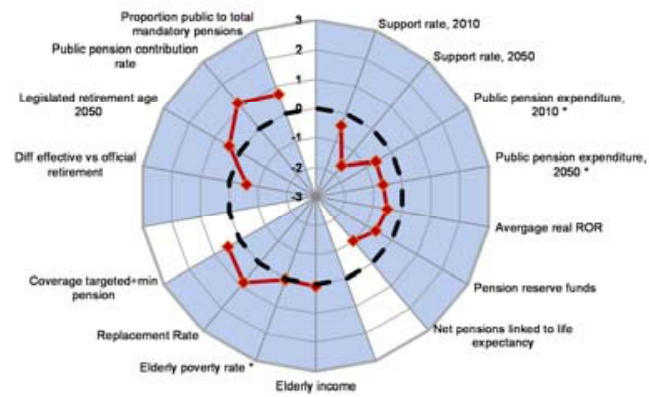

Adequacy
Policy levers $\quad$ Sustainability

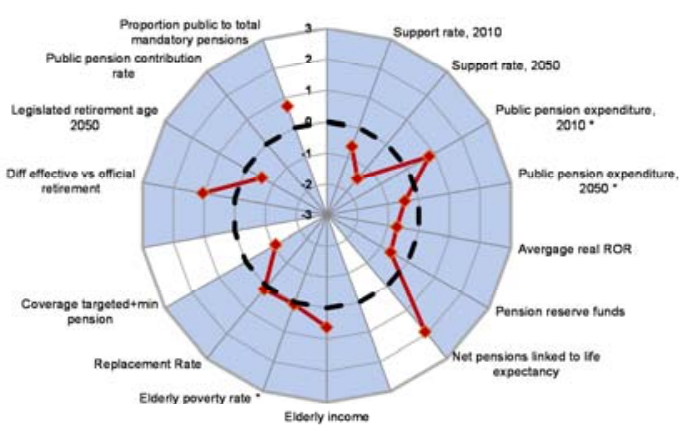

Adequacy

Slovenia

Policy levers

Sustainability

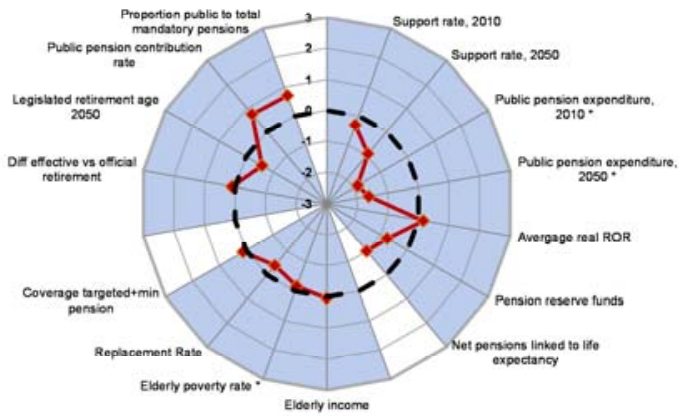

Adequacy

Sweden

$\begin{array}{ll}\text { Policy levers } & \text { Sustainability }\end{array}$

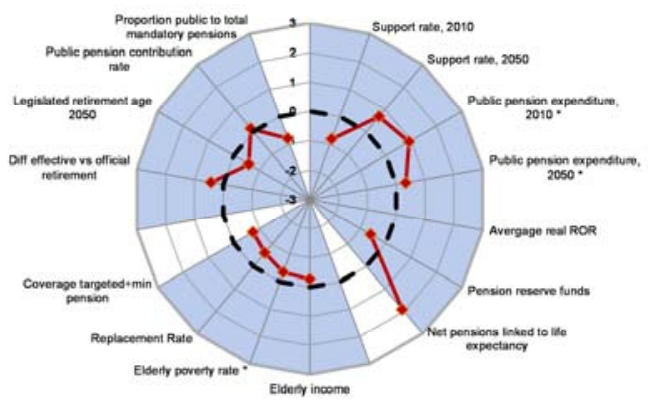

Adequacy 
ECO/WKP(2014)29

Pension system vulnerability indicators (cont.)

Switzerland

Policy levers

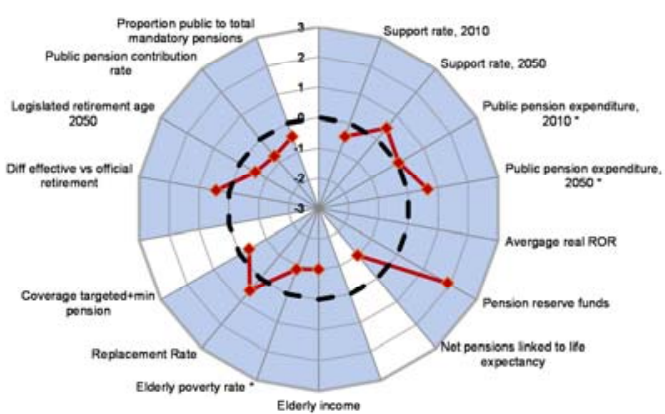

Adequacy

United Kingdom

Policy levers

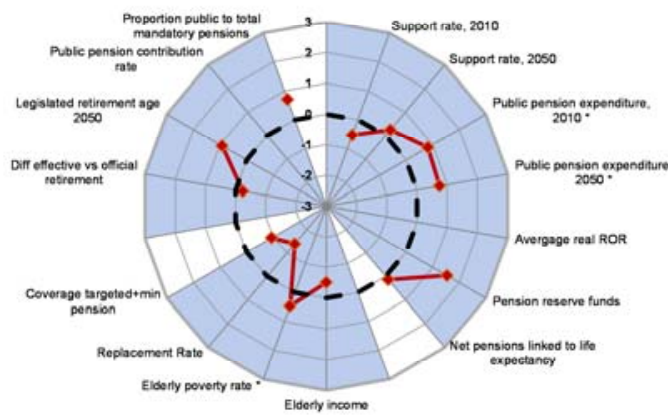

Adequacy
Turkey

$\begin{array}{ll}\text { Policy levers } & \text { Sustainability }\end{array}$

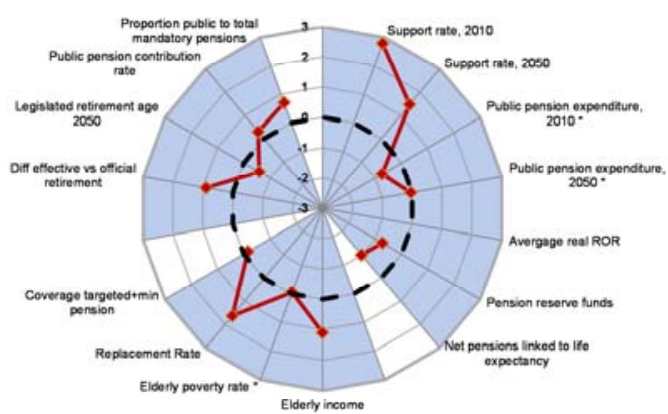

Adequacy

United States

$\begin{array}{ll}\text { Policy levers } & \text { Sustainability }\end{array}$

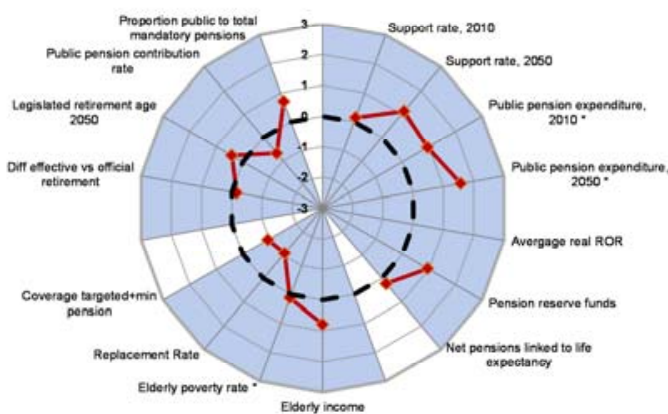

Adequacy

The dotted line represents the OECD average, the solid line represents the country shown. Where the solid line falls inside the OECD average, the variable considered stands below the OECD average. Indicators values are more favourable (e.g. the projected change in expenditure and the poverty gap are lower, while coverage and the contribution rate are higher) the further the observation is removed from the centre of the diamond. The indicators are presented in units of standard deviation.

Legend:

\section{Sustainability}

Support ratio, 2012: population aged 20 to 64 as a percentage of those aged 65 and over.

Support ratio, 2050: see above.

Public pension expenditure, $2010^{*}$ : as per cent of GDP (inverted)

Public pension expenditure, 2050* : as per cent of GDP (inverted)

Average real ROR : Average real rate of investment return, in per cent, 2008-11 average

Pension reserve funds : private pensions, in per cent of GDP, 2011

Net pensions linked to life expectancy: as a per cent of total pensions
Adequacy

Elderly income: as a per cent of total population income, late 2000

Elderly poverty rate* : after taxes and transfers, $60 \%$ line, late 2000 s (inverted) Replacement Rate: Projected average pension as per cent of average individual earnings

Coverage targeted+min pension: per cent of the population age 65 and over Policy levers covered by a targeted or minimum public pension

Diff effective vs official retirement: Difference between the effective and official retirement age, men

Legislated retirement age 2050: planned retirement age, men

Public pension contribution rate: per cent of gross earnings, 2012

Proportion public to total mandatory pensions: balance between public and private provision of mandatory pensions 


\section{WORKING PAPERS}

The full series of Economics Department Working Papers can be consulted at www.oecd.org/eco/workingpapers

1132. Overcoming vulnerabilities of health care systems

(July 2014) by Mauro Pisu

1131. Overcoming vulnerability of unemployment insurance schemes

(July 2014) by Jon Pareliussen

1130. Vulnerability of social institutions: Lessons from the recent crisis and historical episodes (July 2014) by Falilou Fall, Mauro Pisu, Jon Pareliussen and Debbie Bloch

1129. An update of the OECD international trade equations (June 2014) by Myriam Morin and Cyrille Schwellnus

1128. What explains the volume and composition of trade? Industrial evidence from a panel of countries

(June 2014) by Asa Johansson, Przemyslaw Kowalski, Eduardo Olaberria and Dario Pellegrino

1127. Do resources flow to patenting firms: cross-country evidence from firm level data

(June 2014) by Dan Andrews, Chiara Criscuolo and Carlo Menon

1126. Macroprudential policy tools in Norway: Strengthening financial system resilience

(June 2014) by Yosuke Jin, Patrick Lenain and Paul O’Brien

1125. Strengthening competition in Poland

(June 2014) by Balász Égert and Antoine Goujard

1124. Making the labour market work better in Poland

(June 2014) by Hervé Boulhol

1123. Enhancing competition and the business environment in Hungary

(June 2014) by Alvaro Pina

1122. Tackling labour mismatches and promoting mobility in Hungary

(June 2014) by Stéphane Sorbe

1121. Local public finances and municipal reform in Finland

(June 2014) by Christophe André and Clara Garcia

1120. The economic consequences of ageing: the case of Finland

(June 2014) by Christine de la Maisonneuve, Christophe André, Clara Garcia and Vincent Koen

1119. Making the most of skills in Denmark

(June 2014) by Stéphanie Jamet and Vincent Koen

1118. Trade specialisation and policies to foster competition and innovation in Denmark (June 2014) by Müge Adalet McGowan 
ECO/WKP(2014)29

1117. Policies for making the Chilean labour market more inclusive (June 2014) by Aida Caldera Sanchez

1116. Spillover effects from exiting highly expansionary monetary policies

(May 2014) by Łukasz Rawdanowicz, Romain Bouis, Jérôme Brezillon, Ane Kathrine Christensen and Kei-Ichiro Inaba

1115. Economic policies and microeconomic stability: A literature review and some empirics (April 2014) by Paula Garda and Volker Ziemann

1114. How to improve Israel's health-care system (April 2014) by Philip Hemmings

1113. How to improve taxes and transfers in Israel (April 2014) by Philip Hemmings

1112. New evidence on the determinants of industrial specialisation (April 2014) by Asa Johansson and Eduardo Olaberria

1111. Economic growth from the household perspective: GDP and income distribution developments across OECD countries

(April 2014) by Orsetta Causa, Sonia Araujo, Agnès Cavaciuti, Nicolas Ruiz and Zuzana Smidova

1110. Would a growth slowdown in emerging markets spill over to high-income countries? A quantitative assessment

(April 2014) By Patrice Ollivaud, Elena Rusticelli and Cyrille Schwellnus

1109. Short-term indicator models for quarterly GDP growth in the BRIICS: A small-scale bridge model approach

(April 2014) by Thomas Chalaux and Cyrille Schwellnus

1108. The prudential regulation of financial institutions: why regulatory responses to the crisis might not prove sufficient

(March 2014) by William R. White

1107. OECD forecasts during and after the financial crisis: a post mortem

(March 2014) by Nigel Pain, Christine Lewis, Thai-Thanh Dang, Yosuke Jin and

Pete Richardson

1106. Fairly sharing the social impact of the crisis in Greece

(January 2014) by Vassiliki Koutsogeorgopoulou, Manos Matsaganis, Chrysa Leventi and Jan-David Schneider

1105. Dividing the pie in Brazil: income distribution, social policies and the new middle class

(January 2014) by Jens M. Arnold and João Jalles

1104. New indicators of competition law and policy in 2013 for OECD and non-OECD countries (December 2013) by Enrico Alemani, Caroline Klein, Isabell Koske, Cristiana Vitale and Isabelle Wanner 